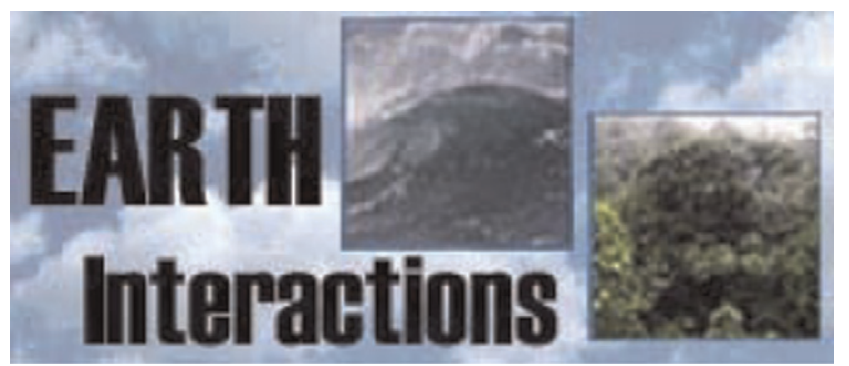

Copyright (C) 2009, Paper 13-010; 75,586 words, 11 Figures, 0 Animations, 4 Tables. http://EarthInteractions.org

\title{
Twentieth-Century Droughts and Their Impacts on Terrestrial Carbon Cycling in China
}

\section{Jingfeng Xiao, ${ }^{,+}$Qianlai Zhuang, ${ }^{\#}$ Eryuan Liang, ${ }^{\circledR, \&}$ A. David McGuire, ${ }^{* *}$ Aaron Moody, ${ }^{++}$David W. Kicklighter, ${ }^{\# \#}$ Xuemei Shao, ${ }^{\&, @ ~ a n d ~ J e r r y ~ M . ~ M e l i l l o " ~}$}

${ }^{+}$Department of Earth and Atmospheric Sciences, and Purdue Climate Change Research Center, Purdue University, West Lafayette, Indiana

\# Department of Earth and Atmospheric Sciences, Department of Agronomy, and Purdue Climate Change Research Center, Purdue University, West Lafayette, Indiana

@ Institute of Tibetan Plateau Research, Chinese Academy of Sciences, Beijing, China

\& Institute of Geographical Sciences and Natural Resources Research, Chinese Academy of Sciences, Beijing, China

** Alaska Cooperative Fish and Wildlife Research Unit, U.S. Geological Survey, University of Alaska Fairbanks, Fairbanks, Alaska

${ }^{++}$Department of Geography, and Curriculum in Ecology, University of North Carolina at Chapel Hill, Chapel Hill, North Carolina

\#\# Ecosystems Center, Marine Biological Laboratory, Woods Hole, Massachusetts

Received 24 July 2008; accepted 5 July 2009

ABSTRACT: Midlatitude regions experienced frequent droughts during the twentieth century, but their impacts on terrestrial carbon balance are unclear. This paper presents a century-scale study of drought effects on the carbon balance of terrestrial ecosystems in China. The authors first characterized the severe extended droughts over the period 1901-2002 using the Palmer drought severity index and then examined how these droughts affected the terrestrial carbon dynamics using tree-ring width chronologies and a process-based biogeochemistry

* Corresponding author address: Jingfeng Xiao, Department of Meteorology, The Pennsylvania State University, University Park, PA 16802.

E-mail address: jing@psu.edu 
Earth Interactions - Volume 13 (2009) - Paper No. 10 • Page 2

model, the Terrestrial Ecosystem Model (TEM). It is found that China suffered from a series of severe extended droughts during the twentieth century. The major drought periods included 1920-30, 1939-47, 1956-58, 1960-63, 196568, 1978-80, and 1999-2002. Most droughts generally reduced net primary productivity (NPP) and net ecosystem productivity (NEP) in large parts of drought-affected areas. Moreover, some of the droughts substantially reduced the countrywide annual NPP and NEP. Out of the seven droughts, three (192030, 1965-68, and 1978-80) caused the countrywide terrestrial ecosystems to switch from a carbon sink to a source, and one (1960-63) substantially reduced the magnitude of the countrywide terrestrial carbon sink. Strong decreases in NPP were mainly responsible for the anomalies in annual NEP during these drought periods. Changes in heterotrophic respiration happened in the same direction, but mostly with smaller magnitude. The results show that severe extended droughts had significant effects on terrestrial carbon cycling in China, although future studies should consider other important processes such as drought-induced mortality and regrowth, land-use change, disturbances (e.g., fire), human management (e.g., fertilization and irrigation), and environmental pollution (e.g., ozone pollution, nitrogen deposition). These drought effects are of particular importance in light of projected widespread summer drying in midlatitude regions during the twenty-first century. Future droughts could lead to a reduced terrestrial carbon sink or even a source and exert a positive feedback to the global climate system.

KEYWORDS: Drought; Carbon cycling; Modeling

\section{Introduction}

Midlatitude regions experienced frequent droughts during the twentieth century (Dai et al. 1998), including severe extended droughts that spanned multiple years and affected a large swath of land (e.g., Schubert et al. 2004). However, the impacts of these severe extended droughts on the terrestrial carbon cycling are unclear (Ciais et al. 2005). Moreover, global climate models project widespread summer drying in midlatitude regions during the twenty-first century (Solomon et al. 2007). Given the strong coupling between carbon and hydrologic cycles, such drying may have significant impacts on terrestrial carbon dynamics and atmospheric carbon dioxide $\left(\mathrm{CO}_{2}\right)$ concentrations and lead to a positive feedback to the global climate system.

Drought is found to significantly affect ecosystem carbon exchange processes (Law et al. 2001; Rambal et al. 2003; Krishnan et al. 2006). First, drought affects stomatal conductance and leaf expansion and limits plant transpiration and water uptake (Sadras and Milroy 1996; Bréda et al. 2006), leading to a reduction in photosynthetic activity (Granier et al. 1999; Reichstein et al. 2003). Second, repeated episodes of drought can cause a decrease in leaf area index in temperate forests (Battaglia et al. 1998; Le Dantec et al. 2000) and promote a decline in gross primary productivity (GPP) (Law et al. 2002). Third, drought alters the production of litter that affects soil carbon pools and the transfer of nutrients from aboveground vegetation to soils (Pedersen and Bille-Hansen 1999; Vasconcelos et al. 2008). Fourth, drought can also reduce carbon allocation from root to soil compartments (Gorissen et al. 2004) and nitrogen cycling (e.g., Schimel et al. 1999). Fifth, the depletion of water in the soil profile can depress microbial processes (Gorissen et al. 2004) and reduce heterotrophic respiration $\left(R_{H}\right)$ (Krishnan et al. 
Earth Interactions - Volume 13 (2009) • Paper No. 10 • Page 3

2006). Decomposition and mineralization will also increase with increasing temperature (Kirschbaum 1995), although acclimation of these processes may exist (Luo et al. 2001). Finally, drought affects net ecosystem productivity (NEP) by directly or indirectly affecting photosynthesis and $R_{H}$.

In spite of this knowledge, historical droughts are rarely examined explicitly in carbon cycle studies at regional or global scales. Studies on the effects of drought on ecosystem carbon fluxes have been based on short-term/seasonal observations and modeling (Law et al. 2001; Reichstein et al. 2003; Rambal et al. 2003; Ciais et al. 2005; Zeng et al. 2005). Moreover, there are a limited number of studies on the effects of long-term severe drought on ecosystem carbon dynamics (Krishnan et al. 2006). Here we used the Palmer drought severity index (PDSI), tree-ring chronologies, and a process-based biogeochemistry model to conduct the first assessment of the impacts of severe extended droughts on the carbon balance of terrestrial ecosystems in China during the twentieth century. This undertaking represents the first century-scale analysis of its kind and is a first step toward a systematic assessment of how severe extended droughts over the entire twentieth century have affected terrestrial carbon cycling across the millions of square kilometers of midlatitude regions.

\section{Methods}

\subsection{Overview}

We characterized the severe extended droughts in China (Figure 1) during the twentieth century and examined their impacts on the terrestrial carbon cycling. First, we calculated the PDSI from a historical monthly climate dataset and then used the PDSI to characterize the severe extended drought events (timing, severity, and extent) during the past century. Second, we collected and developed tree-ring width chronologies from a network of sites and used these chronologies to examine the drought effects on tree growth and ecosystem carbon uptake. Finally, we used a process-based biogeochemical model, the Terrestrial Ecosystem Model (TEM; Raich et al. 1991; Melillo et al. 1993; McGuire et al. 2001; Zhuang et al. 2003) to examine the effects of these severe extended droughts on the carbon cycling of terrestrial ecosystems.

\subsection{Characterization of severe extended droughts}

We used the PDSI (Palmer 1965) to characterize drought events between 1901 and 2002. The PDSI is a measure of cumulative departure relative to the local mean conditions in atmospheric moisture supply and demand at the surface and is perhaps the most widely used index of meteorological drought (Dai et al. 2004). The PDSI has proven a good proxy of surface moisture conditions (Dai et al. 2004; Mika et al. 2005; Szep et al. 2005). It has been routinely used for monitoring droughts in the United States. Moreover, it has been used to study droughts in North America (van der Schrier et al. 2006; Bonsal and Regier 2007), Europe (Lloyd-Hughes and Saunders 2002), Africa (Ntale and Gan 2003), South America (dos Santos and Pereira 1999), and Southeast Asia (Zou et al. 2005). 
Earth Interactions - Volume 13 (2009) • Paper No. 10 • Page 4

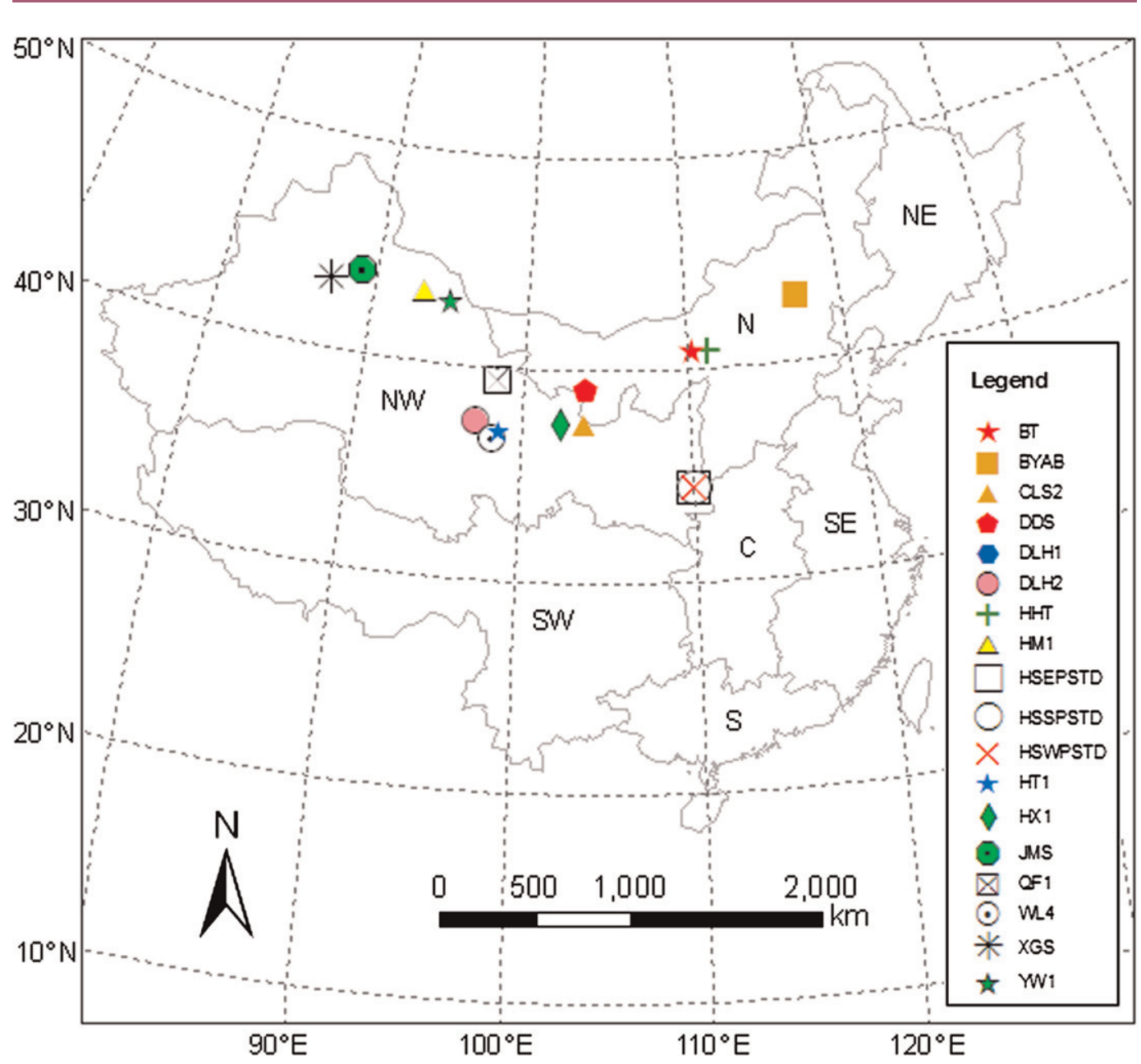

Figure 1. Map of the study area, tree-ring sampling sites, and geographical regions. China is divided into seven geographical regions, including the north $(\mathrm{N})$, northeast (NE), northwest (NW), central China (C), southwest (SW), and south (S).

The PDSI incorporates the antecedent precipitation, moisture supply, and moisture demand, and captures dry and wet spells (Palmer 1965). It uses a two-layer bucket model to calculate soil moisture based on water supply and demand. The maximum amount of water that the entire soil layer can hold is specified by the available water-holding capacity (AWC). The top layer is assumed to be able to hold $2.54 \mathrm{~cm}$ (or $1.0 \mathrm{in}$.) of moisture. The bottom layer of the soil can hold up to (AWC - 2.54) centimeters of moisture. The moisture in the topsoil is used up first when demand exceeds supply and is also recharged first when there is a water surplus.

The PDSI varies roughly between -6.0 and +6.0 , with negative values denoting dry spells and positive values denoting wet spells. Values between -0.5 and 0.5 are considered near normal. Values of -1.0 to -1.9 are interpreted as mild drought, -2.0 to -2.9 as moderate drought, and -3.0 to -3.9 as severe drought. Any PDSI 
Earth Interactions - Volume 13 (2009) • Paper No. 10 • Page 5

Table 1. Site description of the tree-ring width chronologies used in this study.

\begin{tabular}{lcccll}
\hline Site & Lat $\left(^{\circ}\right)$ & Long $\left(^{\circ}\right)$ & Elev $(\mathrm{m})$ & \multicolumn{1}{c}{ Species } & \multicolumn{1}{c}{ Source } \\
\hline HHT & 40.80 & 111.28 & 1300 & Pinus tabulaeformis & Zhang 1994 \\
BT & 40.83 & 110.35 & 460 & Pinus tabulaeformis & Li et al. 1992; Liang et al. 2006 \\
CLS2 & 37.44 & 103.69 & 2512 & Pinus tabulaeformis & Liang et al. 2006 \\
HSE & 34.48 & 110.08 & 2050 & Pinus armandii & Shao and Wu 1994 \\
HSS & 34.48 & 110.08 & 2050 & Pinus armandii & Shao and Wu 1994 \\
HSW & 34.48 & 110.08 & 2100 & Pinus armandii & Shao and Wu 1994 \\
HX1 & 37.49 & 102.44 & 2750 & Picea crassifolia & Liang et al. 2006 \\
DDS & 39.05 & 103.81 & 2666 & Picea crassifolia & Liang et al. 2006 \\
QF1 & 39.42 & 98.44 & 2783 & Picea crassifolia & Liang et al. 2006 \\
DLH1 & 37.47 & 97.24 & 3730 & Sabina przewalskii & Shao et al. 2003; Shao et al. 2005 \\
DLH2 & 37.47 & 97.23 & 3776 & Sabina przewalskii & Shao et al. 2003; Shao et al. 2005 \\
WL4 & 36.68 & 98.42 & 3700 & Sabina przewalskii & Shao et al. 2003; Shao et al. 2005 \\
HT1 & 37.04 & 98.67 & 3736 & Sabina przewalskii & Shao et al. 2003; Shao et al. 2005 \\
HM1 & 43.33 & 93.30 & 3026 & Larix sibirica & Li 1989 \\
YW1 & 43.02 & 95.03 & 2594 & Larix sibirica & Li 1989 \\
JMS & 43.83 & 89.12 & 1985 & Picea schrenkinna & Zhang et al. 1996 \\
XGS & 43.28 & 87.23 & 2070 & Picea schrenkinna & Yuan et al. 2001 \\
BYAB & 43.55 & 117.17 & 1400 & Picea koraiensis & Zhang 1994 \\
\hline
\end{tabular}

values above +4.00 or below -4.00 fall into the "extreme" category of wet spell or drought.

We calculated the PDSI for the period 1901-2002 using monthly temperature and precipitation data at $0.5^{\circ} \times 0.5^{\circ}$ resolution [Climatic Research Unit (CRU) TS 2.1] (Mitchell and Jones 2005). For AWC required for the calculation, we used the water-holding capacity map derived from soil texture by Webb et al. (Webb et al. 2000). We calculated the percentage area experiencing drought for each year by summing the area of those cells affected by drought and then divided by the total land area of the region. We identified severe extended droughts using the percentage area experiencing drought. A drought is defined as a severe extended drought if the drought-affected area (\%) exceeded the average area experiencing drought over the entire century and the drought lasted no less than 3 years.

\subsection{Tree-ring width chronologies}

Tree-ring width chronologies have been used to reconstruct historical droughts (Cook et al. 1999; Cook et al. 2004; Li et al. 2006; Liang et al. 2006). The tree-ring width index is also proven an effective indicator of net primary productivity (NPP) for a variety of forest types (Graumlich et al. 1989; LeBlanc 1996; Rathgeber et al. 2000). The strong correlation between tree-ring width index and NPP makes treering width chronologies a useful means for evaluating the effects of climate variability, including droughts, on NPP of forest ecosystems (Krakauer and Randerson 2003).

We used tree-ring data from a network of sites that involved different tree species and were distributed across the north and northwest (Table 1; Figure 1). We obtained six standardized tree-ring width chronologies, including one chronology of Chinese pine (Pinus tabulaeformis Carr.) from Yinshan Mountains (HHT) (Zhang 1994), two chronologies of Siberian larch (Larix sibirica Ledeb) stands 
Earth Interactions - Volume 13 (2009) • Paper No. 10 • Page 6

from Hami (HM1) and Yiwu (YW1) (Li 1989), two chronologies of Tianshan spruce (Picea schrenkinna var. tianschanica) from Jimusare (JMS) (Zhang et al. 1996) and the Urumqi River Basin (XGS) (Yuan et al. 2001), and one chronology of Hongpi Yunshan (or Korean Pine; Picea koraiensis) from the Baiyinaobao National Reserve (BYAB) in eastern Inner Mongolia (Zhang 1994). We also recrossdated (Liang et al. 2006) a chronology for Chinese pine that was originally collected from Yinshan Mountains (BT) by Li et al. (Li et al. 1992).

In addition, we developed 11 new tree-ring width chronologies, including 3 chronologies of Huashan pine (Pinus armandii Franch.) from the eastern (HSE), southern (HSS), and western (HSW) peaks of the Huashan Mountains (HS) (Shao and Wu 1994); 4 chronologies of Qilian juniper (Sabina przewalskii Kom.) forest stands from the Qilian Mountains: Delingha (DLH1, DLH2), Wulan (WL4), and Halihatu National Forest Park (HT1) (Shao et al. 2003; Shao et al. 2005); and 4 chronologies from the Chanlingshan (CLS2), Haxi (HX1), Dongdashan (DDS), and Qifeng (QF1) forest centers in Gansu Province (Liang et al. 2006). The local variance of tree-ring widths was generally proportional to the local mean, where local was defined as a subinterval of time within the time span covered by the treering widths (Cook and Kairiukstis 1990). We standardized the new chronologies following Cook and Kairiukstis (Cook and Kairiukstis 1990) and Shao and Wu (Shao and Wu 1994). The resulting standardized tree-ring width index had a defined mean of 1.0. Moreover, with standardization, the means of the tree-ring widths were no longer correlated with their variances, and the standardized treering width index thereby exhibited relatively constant variance. This index is an effective means for measuring tree growth due to climate variability (Cook and Kairiukstis 1990).

The 18 tree-ring sampling sites involve different tree species and are distributed across arid and semiarid drought-prone regions in the north and northwest (Table 1; Figure 1). We use these tree-ring chronologies to examine the effects of droughts on tree growth and ecosystem carbon uptake in the north and northwest.

\subsection{Modeling of drought impacts on terrestrial carbon cycling}

\subsubsection{Model description}

We used a process-based biogeochemical model, the TEM (Raich et al. 1991; Melillo et al. 1993; McGuire et al. 2001; Zhuang et al. 2003), to estimate drought effects on ecosystem carbon fluxes. TEM is a global biogeochemistry model that simulates the cycling of carbon, nitrogen, and water among vegetation, soils, and the atmosphere at monthly time steps. The model structure and parameterization are well documented elsewhere (e.g., Raich et al. 1991; Melillo et al. 1993; Tian et al. 1999; McGuire et al. 2001; Zhuang et al. 2003).

In the TEM model, hydrological processes including evapotranspiration (ET) and soil moisture are simulated by the water balance model (WBM) (Vörösmarty et al. 1989). Potential evapotranspiration (PET) is calculated as a function of air temperature, radiation balance, and moisture content of evaporating surfaces. Soil moisture is determined from interactions among rainfall, snowmelt recharge, and PET. Actual evapotranspiration (AET) is then calculated based on PET and total available water in the soil profile. 
Earth Interactions - Volume 13 (2009) - Paper No. 10 • Page 7

The TEM explicitly simulates the carbon fluxes between the terrestrial ecosystems and the biosphere and their responses to drought. The effects of drought on GPP are modeled as a function of ET, which influences leaf phenology and conductance of $\mathrm{CO}_{2}$ to leaves. NPP is calculated as the difference between GPP and autotrophic respiration $\left(R_{A}\right)$. Low soil moisture conditions limit GPP but do not directly affect $R_{A}$, thereby leading to a decline in NPP. Drought also influences nitrogen feedback on carbon cycling as soil moisture alters the rates of nitrogen uptake, soil decomposition, and net nitrogen mineralization (McGuire et al. 1992; Zhuang et al. 2003). The effects of drought on $R_{H}$ are directly modeled as a function of volumetric soil moisture (VSM). In TEM, $R_{H}$ is the loss of carbon from the detrital compartment, which is an aggregated pool of organic carbon in litterfall and soils. Litter is the total production of organic detritus by living vegetation, both above- and belowground, including all carbon losses in abscissed tissues, plant mortality, exudates, leachates, and herbivory (Raich et al. 1991). NPP affects the pool size of soil organic matter through changes in litterfall input. Litterfall transfers organic matter and nutrients from vegetation to soil, and the subsequent decomposition of litter provides nutrients necessary for plant growth. NEP is calculated as the difference between NPP and $R_{H}$, and thus drought influences NEP by directly or indirectly influencing GPP, $R_{A}$, and $R_{H}$. The carbon and nitrogen pool sizes of vegetation and soil are affected by dynamic carbon and nitrogen fluxes (NPP, litterfall $\mathrm{C}$, decomposition, litterfall $\mathrm{N}$, net $\mathrm{N}$ mineralization, $\mathrm{N}$ uptake, etc.).

The model has been extensively tested against field sites (Clein et al. 2000; Amthor et al. 2001), inventory data (Zhuang et al. 2002), satellite data (Zhuang et al. 2003), atmospheric data (McGuire et al. 2001; Zhuang et al. 2003), and hydrologic data (Amthor et al. 2001; Zhuang et al. 2002).

\subsubsection{Driving datasets}

We used spatially explicit information on land cover, climate, soil texture, and elevation as well as historical atmospheric $\mathrm{CO}_{2}$ data to conduct TEM simulations. We used a global monthly climatology dataset gridded at $0.5^{\circ}$ resolution (CRU TS 2.1) (Mitchell and Jones 2005). This dataset has higher spatial resolution, longer temporal coverage, and more strict temporal fidelity than other global climatology datasets. We used three variables including precipitation, mean temperature, and cloudiness.

The land-cover map was derived from the International Geosphere-Biosphere Programme (IGBP) Data and Information System (DIS) DISCover Database (Belward et al. 1999; Loveland et al. 2000). One of the DISCover datasets is the Global Ecosystem dataset with 94 classes, many of which corresponded directly to the land-cover types for the TEM model. The $1 \mathrm{~km} \times 1 \mathrm{~km}$ DISCover dataset was reclassified to the TEM vegetation classification scheme (Melillo et al. 1993). The resulting land-cover map (Figure 2) was used to drive the TEM.

We obtained $1 \mathrm{~km} \times 1 \mathrm{~km}$ elevation data derived from the Shuttle Radar Topography Mission (SRTM) from the Global Land Cover Facility, University of Maryland (http://www.landcover.org). The SRTM is an international project spearheaded by the National Geospatial-Intelligence Agency (NGA), National Aeronautics and Space Administration (NASA), the Italian Space Agency (ASI), and the German 
Earth Interactions - Volume 13 (2009) - Paper No. 10 • Page 8

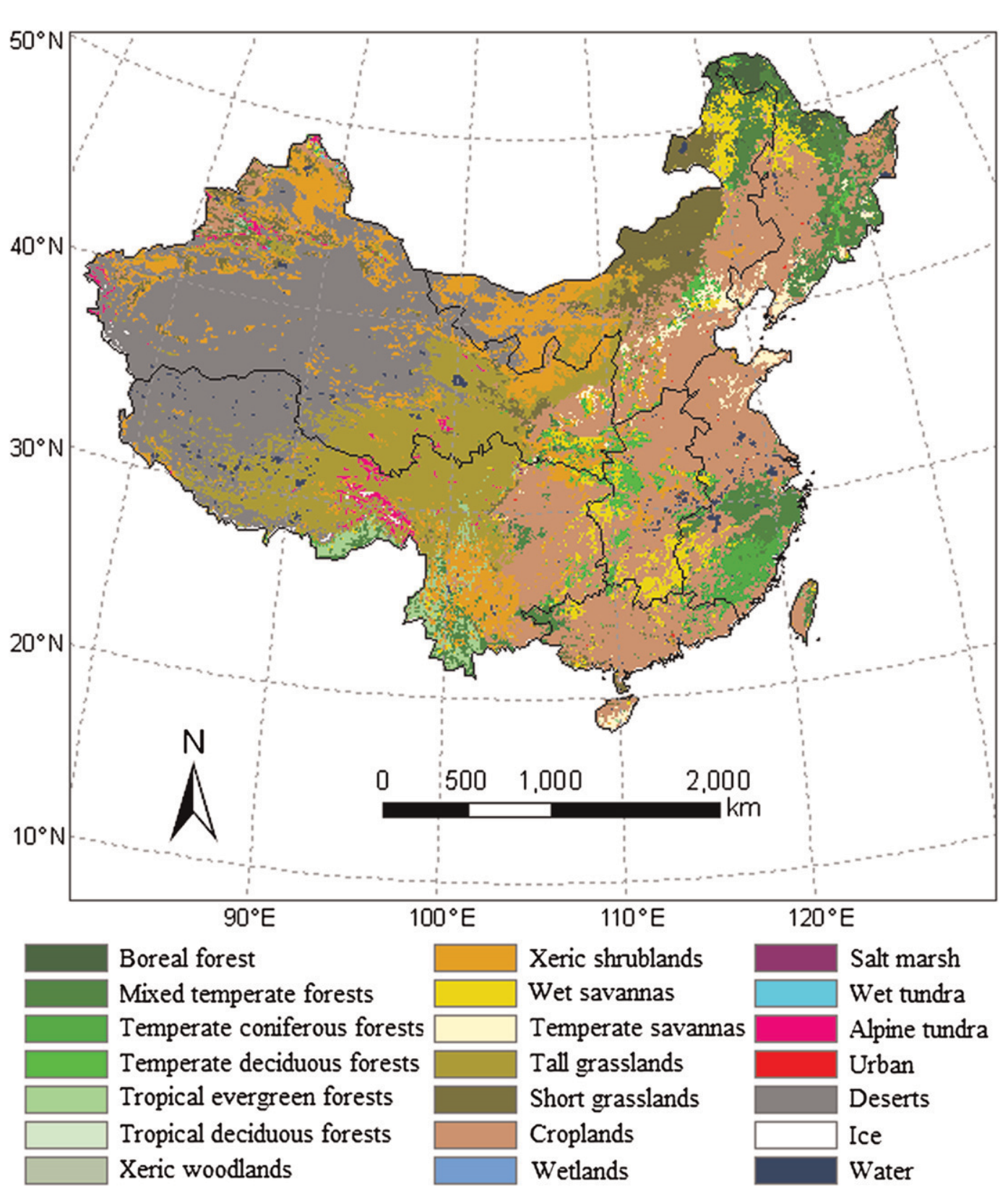

Figure 2. Land-cover map of China $(8 \mathrm{~km} \times 8 \mathrm{~km})$ used in the TEM simulations. The map was reclassified and reaggregated from the IGBP DISCover Database (Belward et al. 1999; Loveland et al. 2000).

Aerospace Center (DLR). The SRTM obtained elevation data on a near-global scale to generate the most complete high-resolution digital topographic database of Earth.

Soil texture data were based on the Food and Agriculture Organization/Civil Service Reform Committee (FAO/CSRC) digitization of the FAO-United Nations Educational, Scientific, and Cultural Organization (UNESCO) [Food and Agricul- 


\section{Earth Interactions - Volume 13 (2009) - Paper No. 10 • Page 9}

ture Organization-United Nations Educational, Scientific, and Cultural Organization (FAO-UNESCO) 1971] soil map. This dataset has $0.5^{\circ} \times 0.5^{\circ}$ spatial resolution.

These driving datasets involve different spatial resolutions, ranging from $1 \mathrm{~km} \times$ $1 \mathrm{~km}$ to $0.5^{\circ} \times 0.5^{\circ}$. We chose to conduct our simulations at $8 \mathrm{~km} \times 8 \mathrm{~km} \mathrm{spa-}$ tial resolution so that we can take advantage of the spatial details provided by the higher-resolution land-cover and elevation datasets $(1 \mathrm{~km} \times 1 \mathrm{~km})$ and in the meantime maintain moderate computation complexity. The driving datasets were therefore aggregated or resampled to $8 \mathrm{~km} \times 8 \mathrm{~km}$.

We also compiled a dataset of historical atmospheric $\mathrm{CO}_{2}$ that extends from 1901 to 2002. For the time period 1901-58, which was before direct observations were available, we derived the time series of the historical atmospheric $\mathrm{CO}_{2}$ mixing ratio using a spline fit to the ice-core record of Etheridge et al. (Etheridge et al. 1996), as

described by McGuire et al. (McGuire et al. 2001). For the time period from 1959 to 2002, we used the observations from Mauna Loa (Keeling and Whorf 2005).

\subsubsection{Model simulation}

We first ran TEM until equilibrium conditions of carbon for each grid cell using the long-term averaged climate and $\mathrm{CO}_{2}$ concentrations from 1901 to 2002 . We then spin up the model for 120 years to account for the influence of climate interannual variability on the initial conditions of the ecosystems. Historical climate data were not available for the period before 1901. Thus, we used the climate data from 1901 to 1940 and repeated 3 times for the spinup. The model was then run with forcing of transient monthly climate and changes of annual atmospheric $\mathrm{CO}_{2}$ concentrations from 1901 to 2002 .

\subsection{Cropland NPP}

We obtained provincial statistics of crop yields from the Chinese Ministry of Agriculture for the period 1998-2002. These statistics involved a variety of crops, such as rice, wheat, corn, sorghum, barley, oats, soybean, peanuts, sunflower, cotton, and sugar beets. For each province, these statistics provided the total yield (tons) of each crop type. We converted the crop yields to NPP to facilitate direct comparison between modeled NPP and crop yields. For each province and crop type, we converted the yields to NPP based on the crop-type specific harvest index, moisture index, and fraction of production allocated aboveground, following Hicke and Lobell (Hicke and Lobell 2004). For croplands, our model did not consider irrigation and chemical fertilization as we focused on examining the impact of natural climate variability on carbon cycling. We compared modeled cropland NPP against crop yield data to assess whether our model can reasonably simulate cropland productivity. We also used the crop yield data to examine the impact of drought on cropland productivity.

\section{Results and discussion}

\subsection{Twentieth-century droughts}

Our PDSI analysis showed that China experienced frequent droughts during the twentieth century (Figure 3). For example, 29.5\%, 33.5\%, and $22.7 \%$ of the 
Earth Interactions - Volume 13 (2009) - Paper No. 10 • Page 10

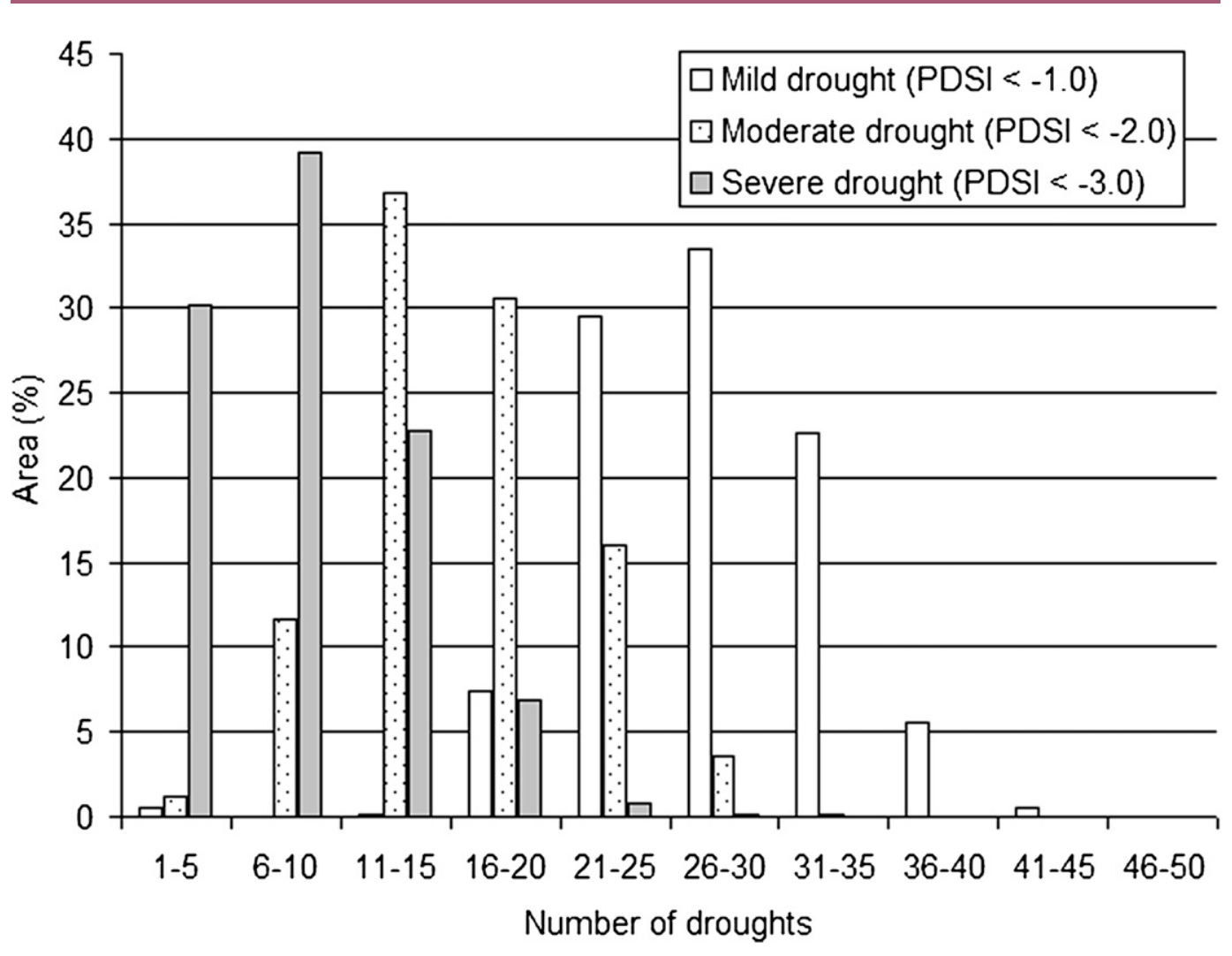

Figure 3. The frequency distribution (\%) of total number of droughts from 1901 to 2002.

country experienced 21-25, 26-30, and 31-35 mild droughts (PDSI $<-1.0$ ), respectively. Taken together, approximately $85.7 \%$ of the country experienced 21-35 mild droughts over the past century; 83.4\% experienced 11-25 moderate droughts (PDSI $<-2.0$ ); 61.2\% experienced 6-15 severe droughts (PDSI $<$ -3.0 ). On average, $26.8 \%, 15.7 \%$, and $8.2 \%$ of the country experienced mild, moderate, and severe droughts each year over the entire century (1901-2002), respectively. The total number of droughts varied substantially over space (Figure 4). The northern half of the country experienced more frequent mild and moderate droughts than its southern counterpart. This was generally consistent with the findings of previous studies (e.g., Bordi et al. 2004; Xin et al. 2006). This spatial pattern is mainly due to the complex topography, the monsoon distribution, and atmospheric circulation patterns across the country. The north and northwest are mainly semiarid and arid regions that usually receive less precipitation. These regions are either dominated by the prevailing westerlies or lie along the border of the Southeast Asian monsoon and are more susceptible to drought. In addition, the meridian circulation anomalies often lead to more rainfall over southern provinces and less rainfall in northern provinces, constituting a pattern of southern flood and northern drought (Xin et al. 2006). 

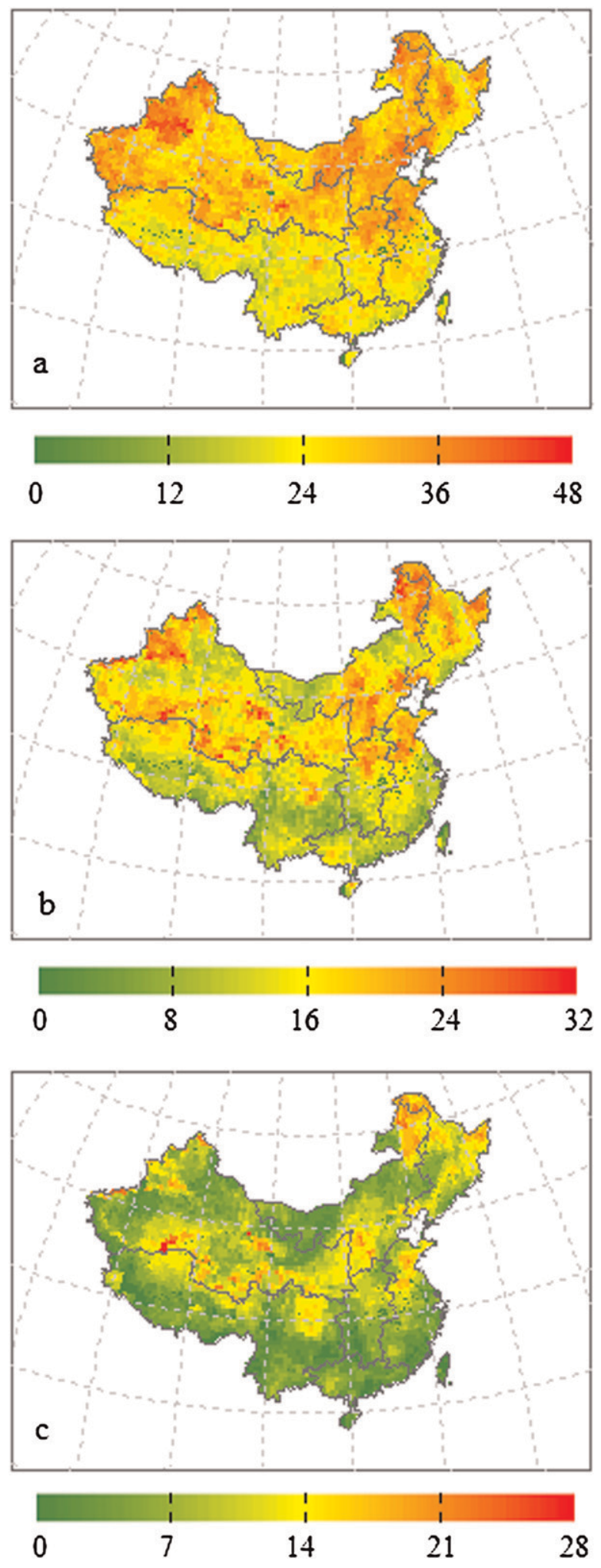

Figure 4. Total number of droughts in each $8 \mathrm{~km} \times 8 \mathrm{~km}$ grid cell from 1901 to 2002 . (a) Mild drought (PDSI <-1.0), (b) moderate drought (PDSI <-2.0), and (c) severe drought (PDSI <-3.0). 
Earth Interactions - Volume 13 (2009) • Paper No. 10 • Page 12

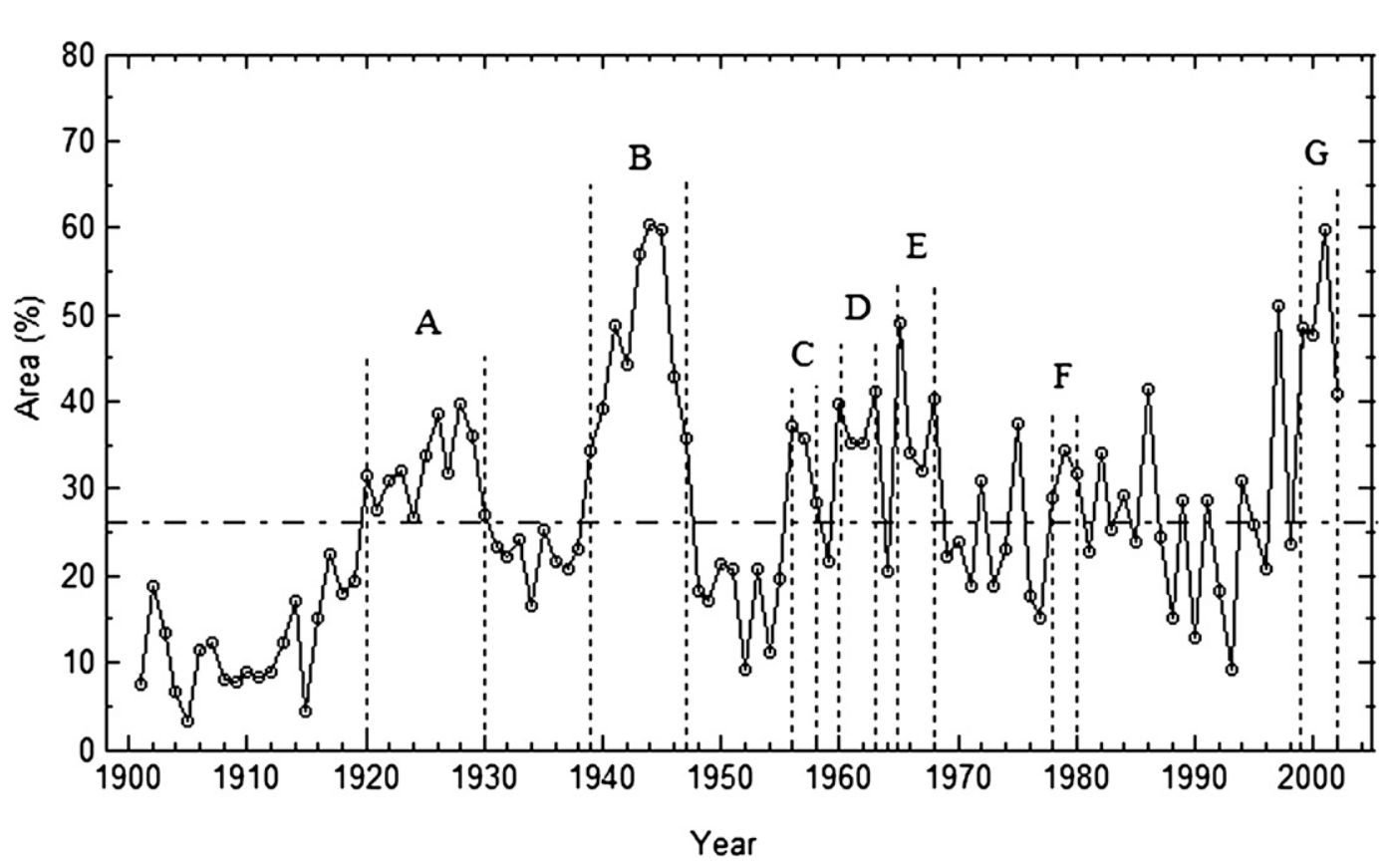

Figure 5. Severe extended drought periods identified using the percentage area experiencing drought (PDSI < - 1.0) across the country: 1920-30 (A), 193947 (B), 1956-58 (C), 1960-63 (D), 1965-68 (E), 1978-80 (F), and 1999-2002 (G). The horizontal line stands for the average percentage area experiencing drought (PDSI <-1.0) over the study period (1901-2002).

Our PDSI analysis showed that China suffered from a series of severe extended droughts during the twentieth century (Figure 5). The major drought periods included 1920-30, 1939-47, 1956-58, 1960-63, 1965-68, 1978-80, and 1999-2002. The duration of these droughts ranged from 3 to 11 years. The two most sustained droughts (1920-30 and 1939-47) lasted 11 and 9 years, respectively. All these droughts were characterized by large precipitation deficits (Figures 6a and 6b). During these drought periods, ET depleted soil moisture with the subsistence of water deficits, which in turn led to even lower ET (Figure 6c).

Several recent studies have examined droughts in China during the last five decades using the PDSI (Zou et al. 2005; Ma and Fu 2006) and other drought indices including the standardized precipitation index (SPI; Bordi et al. 2004). For example, Zou et al. (Zou et al. 2005) examined the variations of droughts over China during the period 1951-2003 and showed that the relatively large dry areas occurred in the 1960s, the late 1970s and the early 1980s, and 1997-2002. Our results agreed well with their findings for the last half of the twentieth century. Tree-ring width chronologies have also been used to reconstruct historical droughts in the north and northwest of the country for a longer period of time (Li et al. 2006; Liang et al. 2006). Our PDSI analysis also agreed with these studies that north and northwest experienced an extremely severe and extended drought during the 1920s. Moreover, our network of tree-ring sites exhibited a consistent decline in tree-ring width index during the 1920s and early 1930s, which further corroborated the 
Earth Interactions - Volume 13 (2009) - Paper No. 10 • Page 13
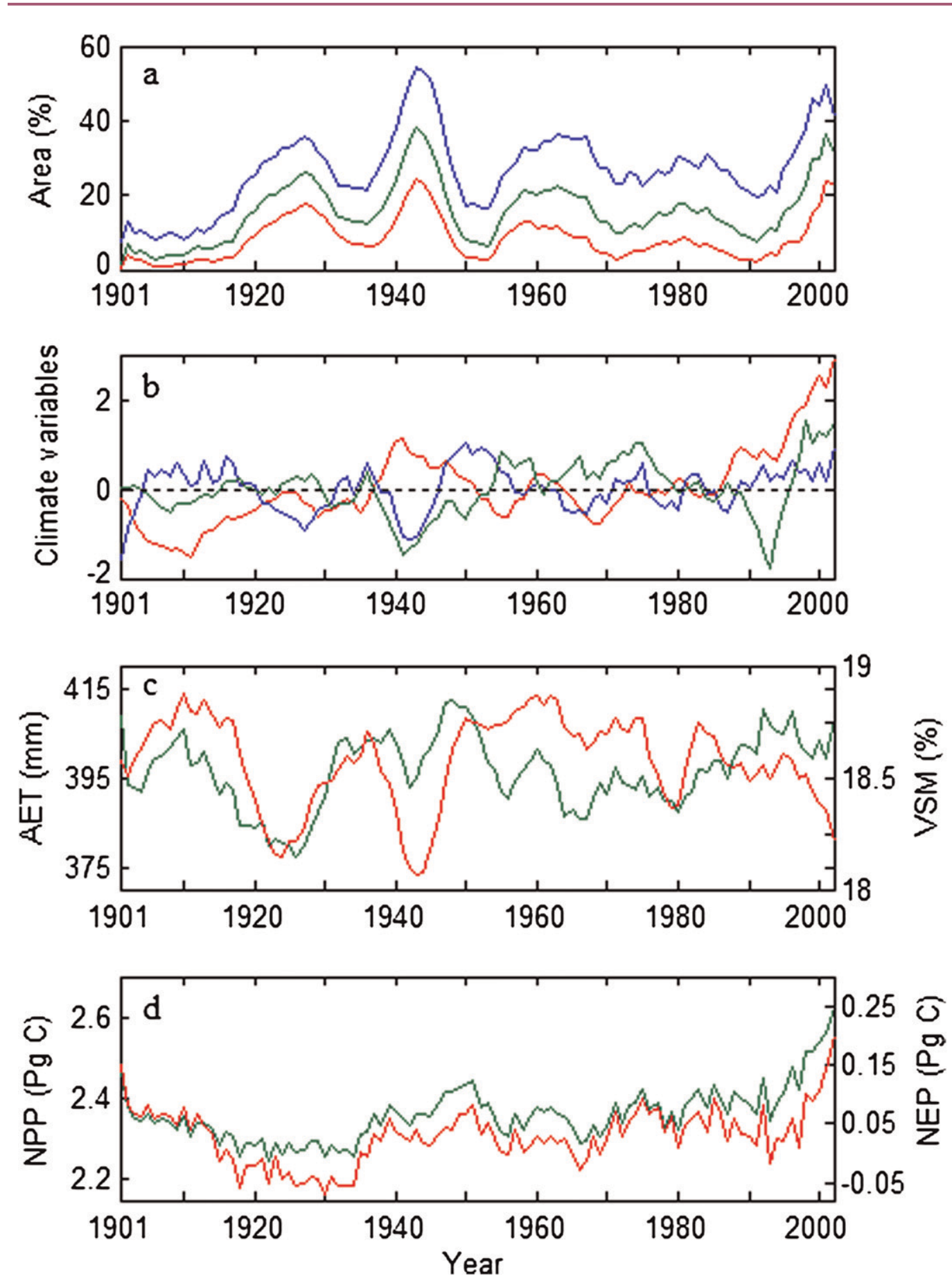

Figure 6. Time series of PDSI, climate variables, AET, VSM, NPP, and NEP averaged over the entire country during 1901-2002. (a) Annual percentage areas in drought conditions: dry areas with PDSI $<-1.0$ (blue line), PDSI $<-2.0$ (green line), and PDSI <-3.0 (red line). (b) Standardized temperature (red line), precipitation (blue line), and cloudiness (green line). (c) Simulated AET (green line) and VSM (red line). (d) Simulated annual NPP ( $\mathrm{PgC} \mathrm{yr}^{-1}$, green line) and NEP (Pg C yr ${ }^{-1}$, red line). Each time series was smoothed using a 5-point moving filter. 


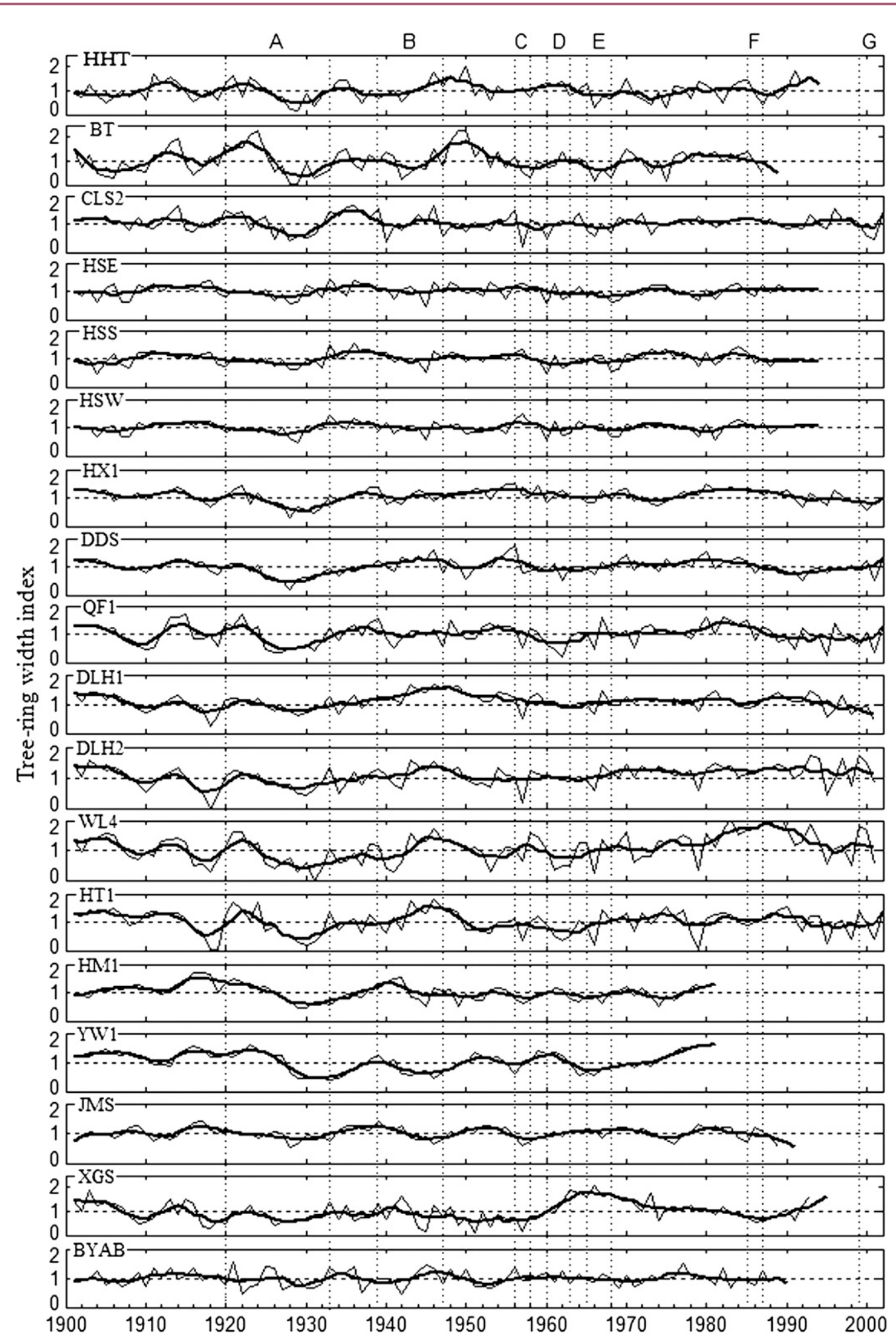

Figure 7. Tree-ring width patterns for the standardized chronologies with 5-yr moving averages (heavy line) from 1901 to 2002. Each severe extended drought period is delineated by two vertical lines: 1920-30 (A), 1939-47 (B), 1956-58 (C), 1960-63 (D), 1965-68 (E), 1978-80 (F), and 1999-2002 (G). 
Earth Interactions - Volume 13 (2009) - Paper No. 10 • Page 15
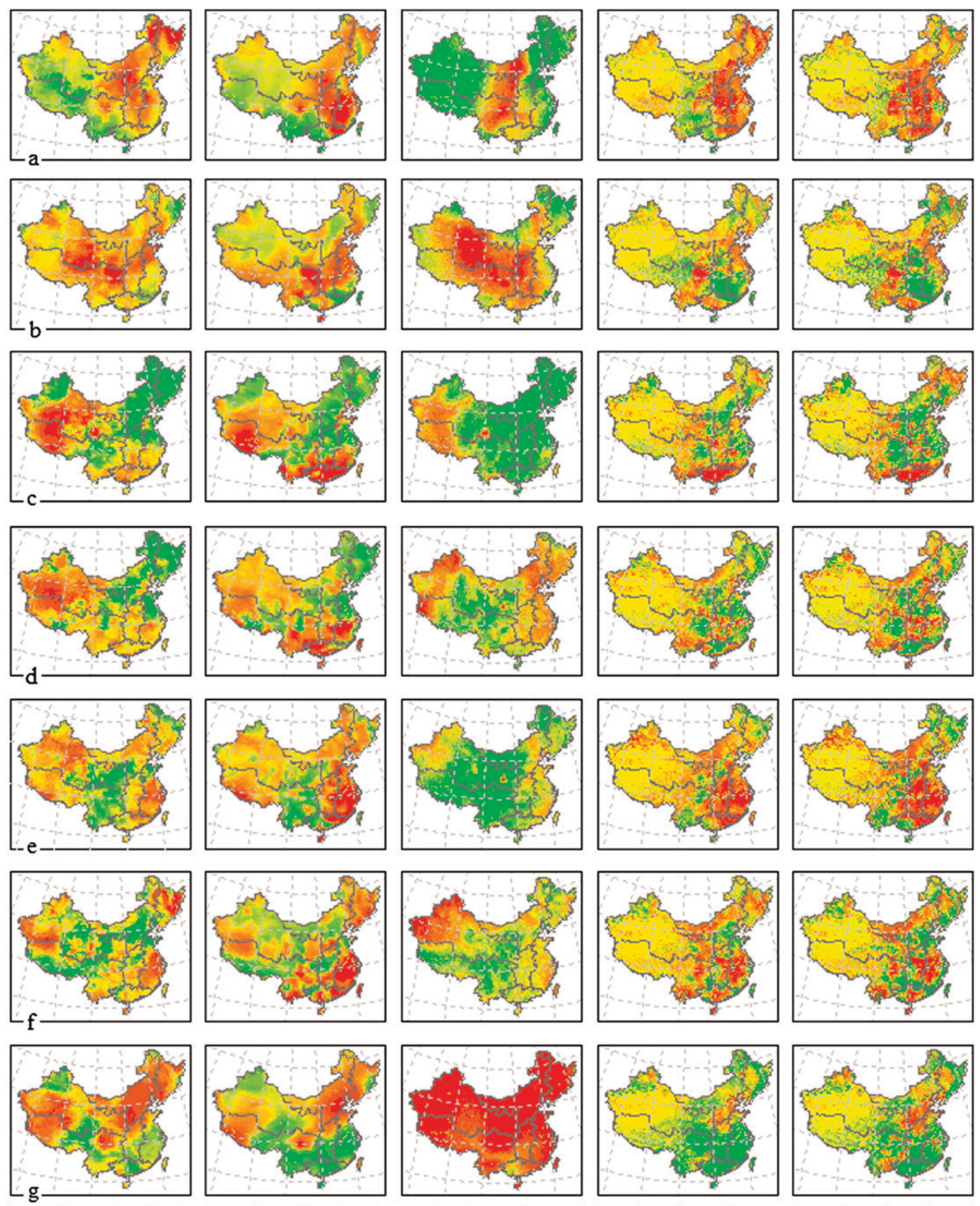

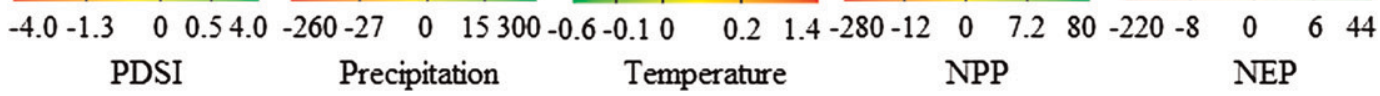

Figure 8. Average annual PDSI over each severe extended drought period and anomalies of average annual precipitation, temperature, NPP, and NEP during the drought period relative to the means over the entire century: (a) 1920-30, (b) 1939-47, (c) 1956-58, (d) 1960-63, (e) 1965-68, (f) 197880 , and (g) 1999-2002. 
Earth Interactions - Volume 13 (2009) - Paper No. 10 • Page 16

occurrence of the sustained drought (Figure 7). Unlike previous studies, our study characterized the severe extended droughts across the entire country and over the entire twentieth century.

The peak percentage area experiencing drought ranged from approximately $34 \%$ to $60 \%$ (Figure 5), showing that each drought affected a large swath of land across the country (Figure 8). Specifically, the 1920s drought extending from 1920 to 1930 mainly affected the eastern half of the country. The 1939-47 drought was slightly shorter than the 1920s drought, but the peak percentage area experiencing drought was larger (Figure 5). The 1939-47 drought affected the north, eastern northeast, the east, the south, and the eastern southwest. The 1956-58 and 1956-58 droughts mainly affected the northwest, the Tibetan Plateau, and the south. The 1965-68 drought affected the northeast, north, western northwest, the Tibetan Plateau, the southeast, central China, and the south. The 1978-80 drought affected the northeast, the southeast, central China, the south, and the western northwest. The 1999-2002 drought mainly affected the north, the northeast, the southwestern northwest, and the Tibetan Plateau.

The variations in droughts and wet spells in China inferred from our PDSI analysis are likely related to teleconnections including the El Niño-Southern Oscillation (ENSO) (Su and Wang 2007) and the North Atlantic Oscillation index (NAOI) (Fu and Zeng 2005). During the typical warm phase of ENSO, surface conditions are drier in most regions of China, especially the north, but wetter than normal in the southern regions of Yangzi River and northwest (Su and Wang 2007). The temporal patterns of droughts in north China are also likely related to the interdecadal change of the atmospheric stationary waves (Dai et al. 2005). In addition, the variations in droughts and wet spells are also likely related to the changes in the strength of the East Asian monsoon. Qian et al. (Qian et al. 2003) suggested that the weakened monsoon during the two periods 1900-30 and 1970-2000 resulting from the weakened thermal contrast between the tropical oceans and the Asian inland region led to large precipitation deficits in the northern part of the country.

\subsection{Drought impacts on terrestrial carbon cycling}

Precipitation deficits and associated low soil moisture and ET along with temperature variations during these drought periods altered annual NPP, $R_{H}$, and NEP. Most severe extended droughts (1920-30, 1956-58, 1960-63, 1965-68, and 197880) substantially reduced annual NPP in large parts of drought-affected regions (Figures 8a and 8c-8f). The reduction in NPP was mainly due to the decrease in photosynthetic activity resulting from the limiting effects of low ET conditions on stomata openness (Granier et al. 1999; Reichstein et al. 2003). For most droughtaffected areas, these droughts also reduced $R_{H}$ but with smaller magnitude, leading to a reduction in annual NEP. For some drought-affected areas, however, these droughts did not reduce annual NPP and NEP likely because higher temperatures during the spring and/or atmospheric $\mathrm{CO}_{2}$ enrichment enhanced photosynthesis, which counteracted the drought effects on NPP. The remaining two droughts (1939-47 and 1999-2002), however, only reduced annual NPP and NEP for some of the drought-affected regions (Figures $8 \mathrm{~b}$ and $8 \mathrm{~g}$ ). For most drought-affected areas during these two drought periods, the negative effects of these two droughts 


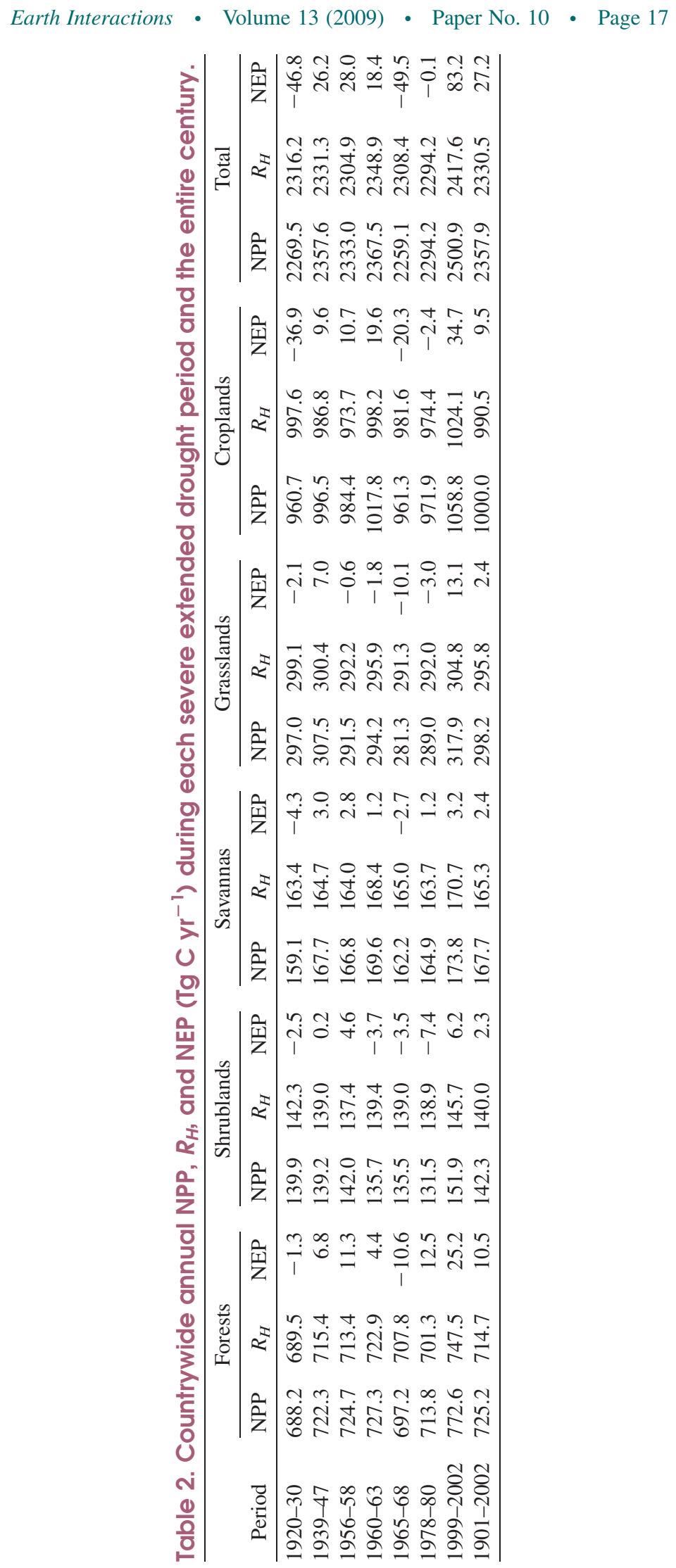


on ecosystem carbon uptake were counteracted by the positive effects of higher temperature (1939-47) or atmospheric $\mathrm{CO}_{2}$ enrichment (1999-2002).

More importantly, most of the severe extended droughts (1920-30, 1956-59, 1965-68, and 1978-80) substantially reduced the countrywide annual NPP (Table 2). Annual $R_{H}$ also changed in the same direction, but with smaller magnitude except for 1956-58 (Table 2). The strong NPP decreases were only partially compensated by decreased $R_{H}$. As a result, three of the droughts (1920-30, 1965-68, and 1978-80) caused countrywide terrestrial ecosystems to switch from a carbon sink to a source, and one drought (1960-63) substantially reduced the size of the countrywide terrestrial carbon sink (Table 2). Specifically, the 1920s drought extending from 1920 to 1930 released a total of 515.0 $\mathrm{Tg} \mathrm{C}$ into the atmosphere and reversed the effect of about 19 years of countrywide net ecosystem carbon sequestration. All ecosystem types (forests, shrublands, savannas, grasslands, and croplands) released carbon into the atmosphere during these drought periods. The drought effect, however, varied with vegetation type (Table 2). This drought substantially affected croplands, with a reduction of $39.3 \mathrm{Tg} \mathrm{C} \mathrm{yr}^{-1}$ in NPP. Historical records also showed that the sustained drought led to substantial reduction in crop yields and severe famines (Deng 1937). Among natural ecosystems, savannas had the largest carbon source, followed by shrublands and grasslands; forests had the smallest carbon source. The magnitude of the carbons source for each vegetation type depended on the severity and extent of the vegetation type affected by the drought, NPP, soil carbon pools, and the area of the vegetation type (Figure 9).

The 1965-68 drought led to a land carbon release of 197.9 Tg C into the atmosphere and reversed the effect of about 7 years of countrywide net ecosystem carbon sequestration (Table 2). Croplands had the largest carbon source, followed by forests and grasslands. Shrublands and savannas had the smallest carbon sources. The 1978-80 drought led to a relatively small carbon source of $0.1 \mathrm{Tg} \mathrm{C} \mathrm{yr}^{-1}$. The drought switched shrublands and grasslands from carbon sinks to sources. This drought had a larger impact on shrublands than any other drought during the period 1901-2002. During the 1956-58 drought, the change in annual $R_{H}$ also happened in the same direction, but with larger magnitude, because of lower temperatures across the vast majority of the country (Table 2). The decrease in annual NPP only partially compensated the decrease in annual $R_{H}$, leading to a slightly higher annual NEP for forests, shrublands, savannas, and croplands during the drought period than the mean over the century. By contrast, the drought resulted in a larger reduction in NPP than in $R_{H}$ for grasslands, leading to a small carbon source.

The 1960-63 drought did not reduce the countrywide annual NPP but substantially reduced annual NEP (Table 2). Precipitation surplus and higher temperature in regions that were not affected by the drought, including the north, the northeast, and northern southeast, enhanced annual NPP in these regions, leading to aboveaverage annual NPP. However, the countrywide annual $R_{H}$ increased more than the countrywide annual NPP, leading to a reduction of $32.6 \%$ in annual NEP. Specifically, NPP increased for forests, savannas, and croplands. The $R_{H}$ increased more than NPP for forests and savannas, leading to reduced NEP. For croplands, however, NPP increased more than $R_{H}$, leading to the doubling of NEP. Both shrublands and grasslands released carbon primarily because of the reduction of NPP.

Plant growth in these different ecosystems has different responses to drought. Under normal climate conditions, plant growth is controlled by a variety of climatic 
Earth Interactions - Volume 13 (2009) - Paper No. 10 • Page 19

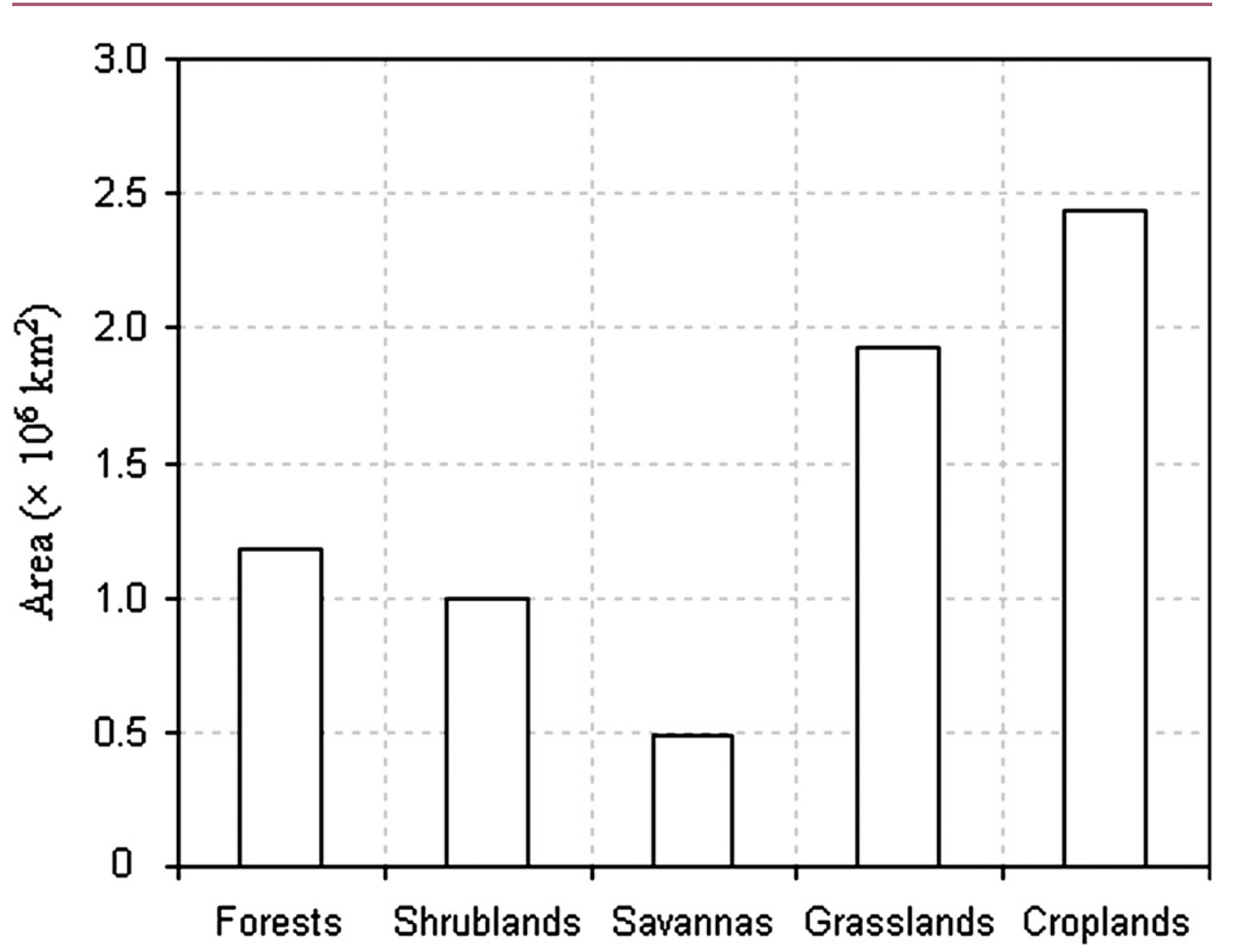

Figure 9. The area of each broad vegetation type in China based on the land-cover map used in the model simulations.

factors such as temperature, precipitation, vapor pressure deficit, and solar radiation (or cloudiness). Churkina and Running (Churkina and Running 1998) and Nemani et al. (Nemani et al. 2003) quantitatively described how temperature, solar radiation, and water availability interactively control plant growth in different regions of the world. Water availability, temperature, and radiation limit plant growth over $40 \%, 33 \%$, and $27 \%$ of the Earth's vegetated surface, respectively (Nemani et al. 2003). In the high latitudes, temperature appeared to be the primary control on NPP; a combination of either temperature and radiation or temperature and water availability limited NPP in the middle latitudes; in the low latitudes, water availability is more dominant than either temperature or radiation (Churkina and Running 1998). China is a big country with diverse ecosystems ranging from humid tropic rain forests south of the Tropic of Cancer to the extremely dry Gobi Desert and from cold boreal forest in the northeast to Tibetan Plateau meadows. In humid regions that are mainly limited by solar radiation, mild drought conditions may increase plant growth as less cloudiness increases incoming photosynthetically active radiation (PAR); for cold biomes, drought may also increase NPP because the accompanying higher temperature and longer growing season could reduce NPP. Under extreme and extended droughts, however, plant growth is predominantly controlled by water availability, and the negative effects of sustained, 


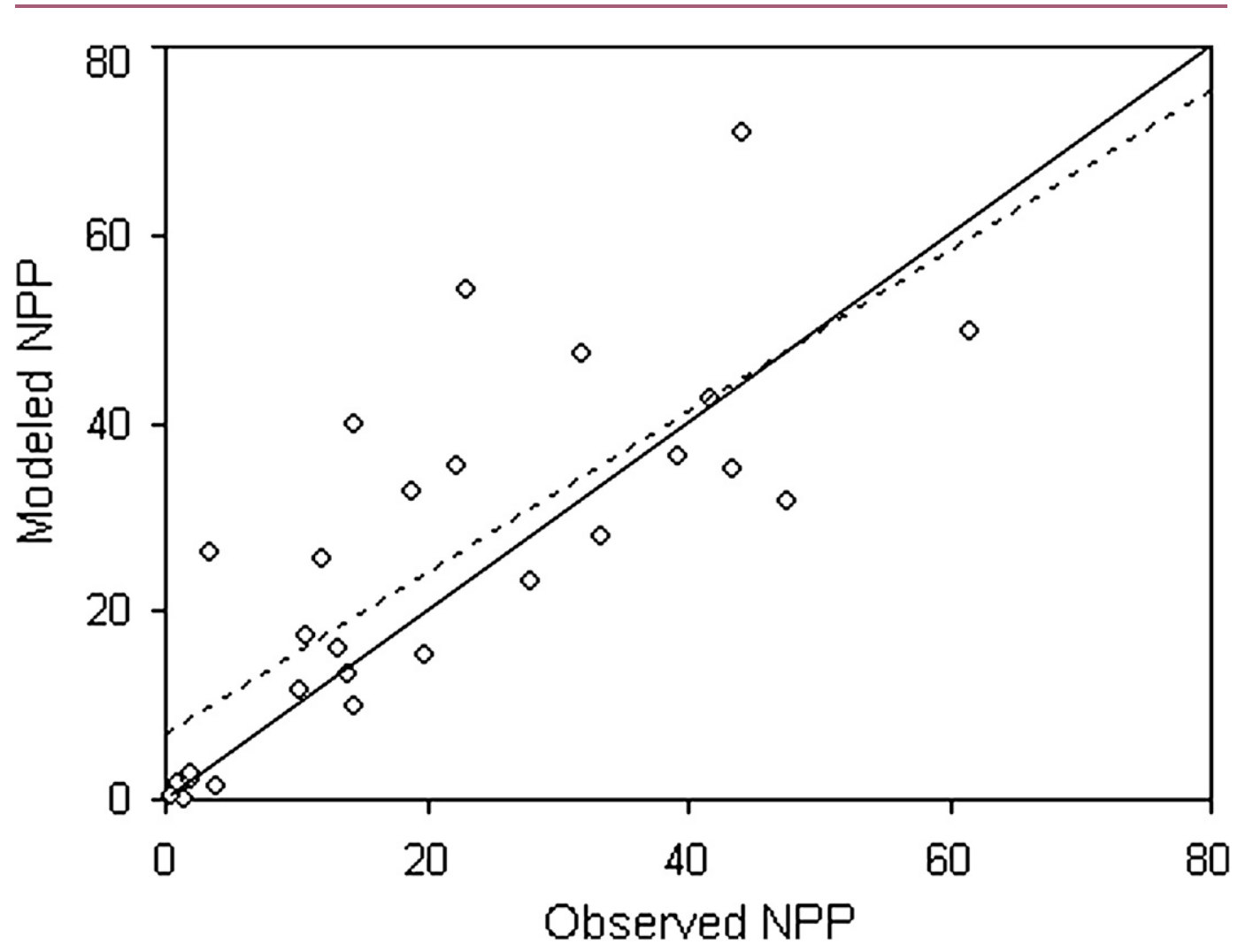

Figure 10. Modeled NPP vs observed NPP in $2002(y=0.86 x+7.07, r=0.78, p<$ 0.000 01). Four provinces including Guangxi, Guangdong, Guizhou, and Hunan were detected as outliers using the Bonferroni correction method and were therefore removed in the analysis.

substantial water deficits outweighed the enhancement effects of higher PAR, higher temperature, or a longer growing season.

Our model did not consider irrigation for croplands. Irrigation is a traditional agricultural management practice in China and can mitigate drought effects on crop yields. Our model thus may have overestimated the negative effects of droughts on ecosystem carbon uptake for croplands. However, in many agricultural regions in China, severe extended droughts substantially lowered water levels of rivers, reservoirs, and lakes, or even dried up these water bodies, thus limiting water for irrigation (Yu 2003). Irrigation, therefore, can only partially mitigate the drought effects during severe extended droughts. Historical documents also showed that severe extended droughts substantially reduced crop yields (Shi et al. 1997; Li et al. 2005). Our modeled NPP was strongly correlated with NPP derived from crop yield data (Figure 10), demonstrating that our model provided reasonable estimates of cropland NPP although our model did not consider irrigation. We also compared the crop yields in 1998 (a wet year) with the average crop yields over the severe extended drought period 1999-2002 (Figure 11). The drought substantially reduced crop yields in most drought-affected provinces relative to the wet year (1998) prior to the drought. We therefore believe that, as our model 


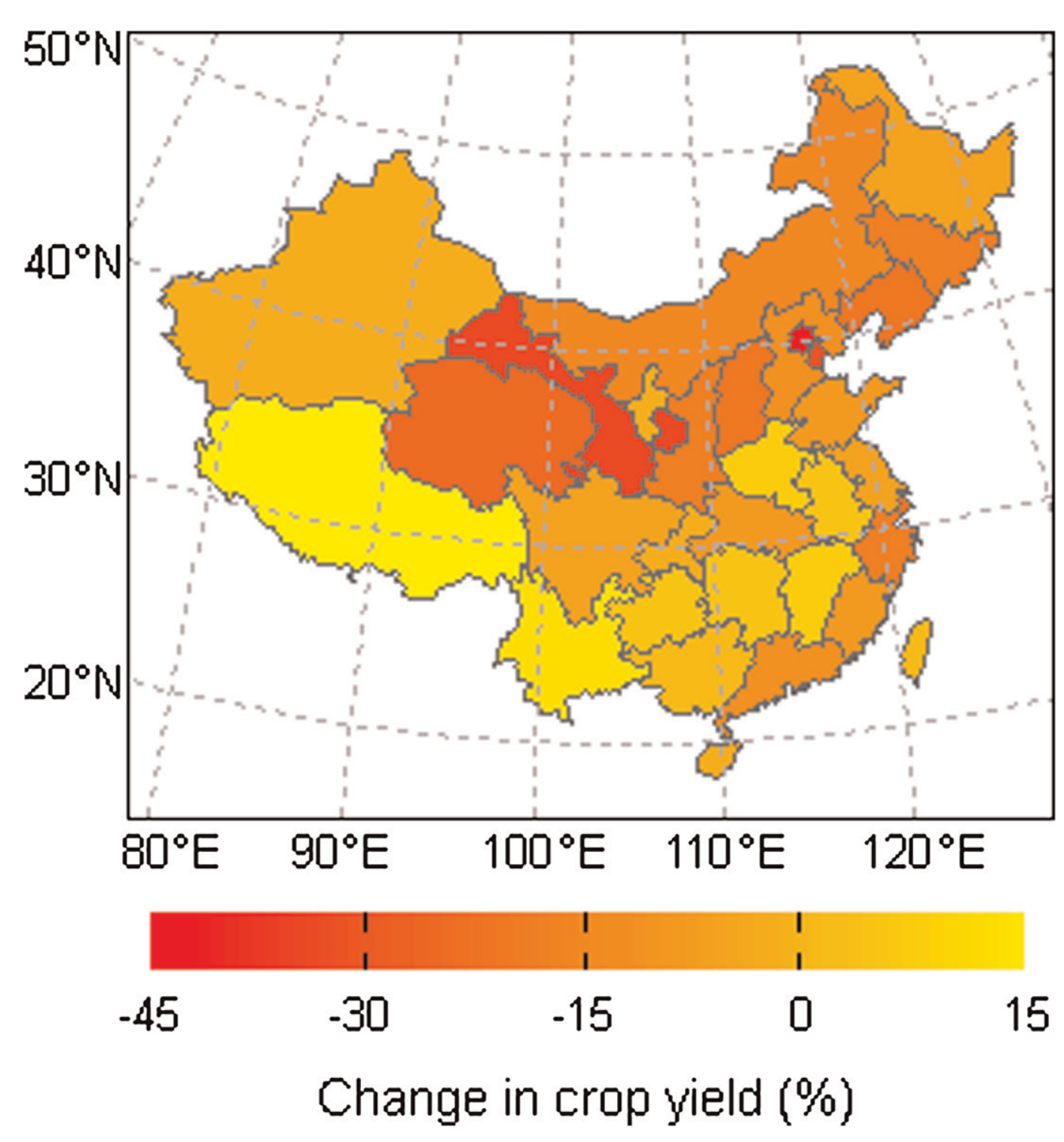

Figure 11. The change between the crop yield in 1998 (a wet year) and the average crop yield over the severe extend drought 1999-2002 for each province. Negative and positive values denote decreases and increases in crop yields from 1998 to 1999-2002, respectively.

simulations indicated, the severe extended droughts had significant impacts on annual NPP and NEP of croplands, although we may have overestimated the drought effects on crop yields without considering irrigation.

\subsection{Drought effects inferred from tree-ring width chronologies}

Our tree-ring width chronologies were generally consistent with our modeled NPP in the north and northwest (Table 3; Figure 7). Four droughts, including 
Earth Interactions - Volume 13 (2009) - Paper No. 10 • Page 22

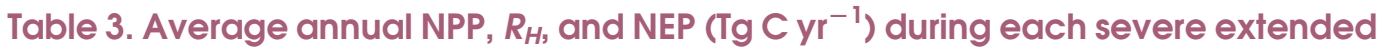
drought period and the entire century over the tree-ring sampling area.

\begin{tabular}{lccccccr}
\hline & \multicolumn{3}{c}{ Vegetated } & & \multicolumn{3}{c}{ Forested } \\
\cline { 2 - 3 } Period & NPP & $R_{H}$ & NEP & & NPP & $R_{H}$ & NEP \\
\hline $1920-24$ & 406.2 & 426.1 & -19.9 & 77.4 & 79.2 & -1.8 \\
$1926-33$ & 413.3 & 425.4 & -12.1 & 75.8 & 79.8 & -4.0 \\
$1939-47$ & 433.8 & 432.2 & 1.6 & 83.1 & 84.7 & -1.6 \\
$1956-58$ & 447.0 & 429.6 & 17.4 & 91.2 & 88.3 & 2.9 \\
$1960-63$ & 436.6 & 437.5 & -1.0 & 89.5 & 88.9 & 0.6 \\
$1965-68$ & 415.6 & 429.5 & -13.9 & 87.5 & 85.9 & 1.6 \\
$1978-80$ & 433.8 & 427.9 & 5.8 & 90.3 & 85.2 & 5.1 \\
$1999-2002$ & 455.0 & 450.5 & 4.5 & 90.6 & 90.0 & 0.6 \\
$1901-2002$ & 439.5 & 432.2 & 7.3 & 88.2 & 85.8 & 2.4 \\
\hline
\end{tabular}

1920s, 1939-47, 1965-68, and 1999-2002, affected the majority of the treesampling area (Figures 1 and 6) and reduced annual NPP and/or NEP (Table 3). The 1920s drought extended into the early 1930s in this area, consisting of two dry spells including 1920-24 and 1926-33 and a relatively wet year (1925) in between. Each dry spell reduced annual NPP and also switched forested ecosystems in the region from a carbon sink to a source. During the 1920s drought, the tree-ring width index declined for all the tree-ring sites in the region, with a slight decline for XGS and BYAB and a substantial decline for all other sites.

The 1939-47 drought also reduced annual NPP of forested ecosystems and led to a carbon source. The tree-ring width index declined almost throughout the entire drought period for the BT, YW1, and JMS sites, and for some years of the drought period for all other sites except DDS and DLH1. The tree-ring width index did not exhibit a consistent decline across the sites because temperature is a dominant limiting factor for the majority of the sites because of their high elevations (Leal et al. 2007) and the exceptionally high temperatures during this period enhanced tree growth at these sites.

The 1965-68 drought reduced both annual NPP and NEP. During this period, the tree-ring width index decreased for most of the sites that were affected by the drought. During the 1999-2002 drought, annual NPP increased with larger magnitude than annual $R_{H}$, leading to a reduced carbon sink. These droughts also reduced the tree-ring width index (Figure 7). All the eight sites (CLS2, HX1, DDS, QF1, DLH1, DLH2, WL4, and HT1) that had tree-ring chronologies available during the drought period exhibited a substantial decline in tree-ring width index.

The remaining three droughts (1956-58, 1960-63, and 1978-80) only affected a part of the tree-ring sampling area (Figure 8). Our tree-ring chronologies and model simulations showed that these droughts reduced tree-ring width index for some of the sites (Figure 7) and generally did not reduce the regionwide annual NPP and NEP of forested ecosystems (Table 3).

The reduction in tree growth is generally consistent with the decline in our modeled NPP for forested ecosystems in the region. Although changes in tree-ring width do not provide information about heterotrophic respiration or belowground carbon stocks (Jacoby and D'Arrigo 1997), the reduction in tree-ring width and modeled NPP was generally accompanied by a decline in modeled NEP. These 
Earth Interactions - Volume 13 (2009) - Paper No. 10 • Page 23

results further demonstrated that severe extended droughts had substantial impacts on ecosystem carbon fluxes.

\subsection{Mitigation effects of warmer temperatures and $\mathrm{CO}_{2}$ enrichment}

Unlike other severe extend drought events, the 1939-47 and 1999-2002 droughts did not reduce the countrywide annual NPP and NEP relative to means over the century. The 1939-47 drought affected the northwest and the Tibetan Plateau, which are dominated by desert and subalpine ecosystems that normally have low productivity. A drought in areas normally with low productivity would have less of influence on countrywide carbon dynamics than if the drought occurred in area normally with high productivity (Orwig and Abrams 1997). In addition, higher temperature during the drought period enhanced NPP (Figure 8b). The carbon loss in drought-affected areas was counteracted by the carbon gains because of growth enhancement in other areas. To quantify the effects of increased temperature, we conducted a separate model simulation with air temperature held constant over the period 1901-2002. Specifically, we used the normal monthly temperatures averaged over the study period as well as transient precipitation and atmospheric $\mathrm{CO}_{2}$ data to drive the model. We found that, had air temperatures been normal, the 1939-47 drought would have substantially reduced average annual NEP to $12.1 \mathrm{Tg} \mathrm{C} \mathrm{yr}^{-1}$, a reduction of $55.8 \%$. However, because of growth enhancement driven by higher temperatures, the sink was only reduced to $26.2 \mathrm{Tg} \mathrm{C} \mathrm{yr}^{-1}$, a reduction of $7.5 \%$.

The 1999-2002 drought did not reduce the countrywide ecosystem carbon fluxes because $\mathrm{CO}_{2}$ fertilization enhanced annual NPP (Table 2). To test for the effects of $\mathrm{CO}_{2}$ fertilization we conducted another simulation with average atmospheric $\mathrm{CO}_{2}$ concentrations and transient temperature and precipitation. With constant atmospheric $\mathrm{CO}_{2}$, the 1999-2002 drought would have substantially reduced average annual NEP (11.9 $\mathrm{Tg} \mathrm{C} \mathrm{yr}^{-1}$ ) relative to the mean over the entire century. This suggests that the carbon loss in drought-affected areas was smaller than the carbon gains because of the growth enhancement by $\mathrm{CO}_{2}$ fertilization in other areas, leading to above-average annual NEP during the drought period. Meanwhile, positive temperature anomalies increased the countrywide annual $R_{H}$ by $3.8 \%$. The increase in $R_{H}$ only partially compensated the increase in annual NPP, which also contributed to above-average annual NEP.

However, it does not follow that these droughts did not have significant impacts on the terrestrial carbon cycling. These two sustained droughts did not reduce countrywide ecosystem carbon fluxes mainly because of the enhancement effects of higher temperature and/or $\mathrm{CO}_{2}$ enrichment as well as carbon gains in areas that were not affected by drought. These two droughts actually had significant implications for the terrestrial carbon cycling in that they counteracted the enhancement effects of higher temperature and/or atmospheric $\mathrm{CO}_{2}$ concentration on annual NPP. Without these droughts, the countrywide terrestrial ecosystems would have provided larger carbon sinks during these two periods.

Field studies showed that atmospheric $\mathrm{CO}_{2}$ enrichment could enhance NPP (Norby et al. 2005) and mitigate the negative effects of drought on photosynthesis and net ecosystem carbon exchange (Li et al. 2007; Manderscheid and Weigel 2007). Our results showed that atmospheric $\mathrm{CO}_{2}$ enrichment could counteract the negative effects of drought on ecosystem carbon uptake at the regional 
Earth Interactions - Volume 13 (2009) • Paper No. 10 • Page 24

scale, and lead to higher ecosystem carbon sequestration despite the severe extended droughts. Mu et al. (Mu et al. 2008) used a process-based ecosystem model, Biome-BGC (biogeochemical cycles), to assess the effects of changing climate and elevated atmospheric $\mathrm{CO}_{2}$ on terrestrial carbon cycling in China. Their results also suggested that changes in climate reduced carbon storage in China's ecosystems, but increasing $\mathrm{CO}_{2}$ compensated for these adverse effects of climate change. Zeng et al. (Zeng et al. 2005) suggested that the rare drought that occurred from 1998 to 2002 across much of the Northern Hemisphere midlatitude regions led to a large carbon source. Our results agreed with Zeng et al. (Zeng et al. 2005) that the drought affected a large part of China and substantially reduced net ecosystem carbon sequestration in the drought-affected region. However, our results showed that the drought did not reverse the effect of the countrywide ecosystem carbon sequestration mainly because of the growth enhancement effects of increasing $\mathrm{CO}_{2}$ concentrations, particularly in areas that were not affected by the drought. Our results indicated that the large carbon source during the 1999-2002 drought period in midlatitude regions may not be largely due to the negative effects of the drought on ecosystem productivity but to other factors.

\subsection{Implications}

Our results showed that severe extended droughts during the twentieth century had significant impacts on terrestrial carbon cycling, suggesting that severe extended droughts should be considered in regional carbon budget studies. The magnitude of the terrestrial carbon sink could be substantially overestimated without considering extreme climate events. Some previous studies examined the responses of terrestrial ecosystems to the interannual variability in climate at decadal to century scales (e.g., McGuire et al. 2001; Cao et al. 2003; Albani et al. 2006) and thus may have implicitly considered drought effects on ecosystem carbon fluxes. However, these studies did not explicitly examine the effects of severe extended droughts on terrestrial carbon cycling. Moreover, many carbon budget studies are based on measurements or simulations for a short period of time (e.g., several years) that do not include severe extended droughts and overlook the importance of severe extended droughts on carbon cycling (e.g., Pacala et al. 2001). The magnitude of the terrestrial carbon sink estimated for a short period of time may not provide a real picture of the terrestrial carbon budgets in the long run, as decadal-scale ecosystem carbon sequestration could be undone by a single severe extended drought. Our results highlight the role of severe extended droughts in the terrestrial carbon cycle in China, although future studies should include other important processes such as drought-induced mortality and regrowth (Hogg et al. 2008), land-use change (Trusilova and Churkina 2008), disturbances (e.g., fire) (Xiao and Zhuang 2007), human management (e.g., fertilization and irrigation) (Xiao and Moody 2004), and environmental pollution (e.g., ozone pollution, nitrogen deposition) (Ren et al. 2007; Sutton et al. 2008).

Our results suggested that drought effects are of particular importance in light of the projected widespread summer drying in midlatitude regions during the twenty-first century (Solomon et al. 2007). The severe extended droughts during the twentieth century identified in this study should not be regarded as isolated 
Earth Interactions - Volume 13 (2009) - Paper No. 10 • Page 25

Table 4. Countrywide GPP, NPP, $\boldsymbol{R}_{H}$, and NEP averaged over the period 1901-2002 for the sensitivity analysis of cloudiness with six additional model simulations. In these additional simulations, cloudiness data were changed by $\pm 5 \%, \pm 12 \%$, and $\pm 25 \%$.

\begin{tabular}{ccccc}
\hline Cloudiness & $\mathrm{GPP}\left(\mathrm{Pg} \mathrm{C} \mathrm{yr}^{-1}\right)$ & $\mathrm{NPP}\left(\mathrm{Pg} \mathrm{C} \mathrm{yr}^{-1}\right)$ & $R_{H}\left(\mathrm{Pg} \mathrm{C} \mathrm{yr}^{-1}\right)$ & $\mathrm{NEP}\left(\mathrm{Tg} \mathrm{C} \mathrm{yr}^{-1}\right)$ \\
\hline$-25 \%$ & 4.32 & 2.18 & 2.16 & 25.69 \\
$-12 \%$ & 4.47 & 2.28 & 2.25 & 26.33 \\
$-5 \%$ & 4.54 & 2.33 & 2.30 & 26.89 \\
Normal & 4.59 & 2.36 & 2.33 & 27.24 \\
$+5 \%$ & 4.63 & 2.38 & 2.35 & 27.45 \\
$+12 \%$ & 4.69 & 2.41 & 2.38 & 27.69 \\
$+25 \%$ & 4.77 & 2.45 & 2.43 & 28.17 \\
\hline
\end{tabular}

extreme accidents but as events that might occur with increasing frequencies and severity in the future. Drought therefore will likely have a larger impact on terrestrial carbon cycling. Drought will at least partly counteract the enhancement effects of increasing temperature and atmospheric $\mathrm{CO}_{2}$ concentrations on NPP and NEP. Severe extended droughts similar to the 1920-30 and 1965-68 droughts may reduce terrestrial carbon sink or even switch terrestrial ecosystems from a carbon sink to a source. Moreover, future droughts will also likely affect fire regimes and indirectly affect the net carbon flux between the terrestrial biosphere and the atmosphere (Xiao and Zhuang 2007). The projections of terrestrial carbon dynamics during the twenty-first century are highly uncertain under global climate change scenarios (Hurtt et al. 2002), and future droughts could lead to another significant source of uncertainty of carbon sink and source activity.

\subsection{Sensitivity analysis}

In TEM, we used cloudiness along with air temperature and precipitation from the CRU TS 2.1 dataset (Mitchell and Jones 2005) to simulate GPP. In this dataset, cloudiness is one of the secondary variables. The data of secondary variables are less comprehensive than those of the primary variables (precipitation, mean temperature, and diurnal temperature range) because CRU has only recently made efforts to obtain the secondary variables and they are also less widely measured than temperature and precipitation (New et al. 2000). Moreover, clouds have traditionally been observed visually by trained technicians at weather stations, and the resulting observations are subjective measures of sky cover and may have substantial uncertainties (Dai et al. 2006). Although averaging over large samples may substantially reduce the errors, systematic changes in observational practice (e.g., from $1 / 10$ to $1 / 8$ units) may lead to inhomogeneities in surface cloud data (Karl and Steurer 1990; Dai et al. 2006). In addition, Qian et al. (Qian et al. 2006) showed that the total cloud cover has increased, while solar radiation has decreased in China from 1954 to 2001, indicating that increased air pollution may have reduced surface incoming solar radiation. These uncertainties associated with cloudiness may propagate through our model and lead to uncertainties in carbon fluxes.

We conducted a sensitivity analysis to examine the impact of the uncertainties in cloudiness data on modeled carbon fluxes. We conducted six additional model 
Earth Interactions - Volume 13 (2009) - Paper No. 10 • Page 26

simulations with actual air temperature and precipitation data while increasing or decreasing cloudiness by $5 \%, 12 \%$, and $25 \%$. Table 4 shows the countrywide GPP, NPP, $R_{H}$, and NEP averaged over the period 1901-2002 for the six additional model simulations. Our sensitivity analysis showed that these prescribed changes in cloudiness led to only 1\%-5.9\% changes in annual GPP, $1 \%-7.4 \%$ in annual NPP and $R_{H}$, and $0.8 \%-5.7 \%$ in NEP. Moreover, for long-term change analyses, continuity and homogeneity of the record are most important, whereas the systematic biases may affect only the magnitude of the trends slightly (Dai et al. 2006). Therefore, we believe that our model simulations are appropriate for examining the effects of droughts on ecosystem carbon fluxes and regional carbon budgets despite the uncertainties associated with cloudiness data.

\section{Conclusions}

Our results showed that China suffered from a series of severe extended droughts during the twentieth century that were characterized by long duration and large spatial extent. Our model simulations and tree-ring width chronologies showed that these severe extended droughts had significant impacts on the terrestrial carbon cycling. Most droughts substantially reduced annual NPP and NEP in large parts of drought-affected regions. More importantly, some of the droughts substantially reduced the countrywide annual NPP and NEP. Strong decreases in NPP were mainly responsible for the anomalies in annual NEP during these severe extended drought periods. Changes in $R_{H}$ happened in the same direction, but mostly with smaller magnitude. Most notably, ecosystem carbon sequestration accumulated over a number of years could be undone by a single severe extended drought. Our results suggested that severe extended droughts should be explicitly considered in future regional or global carbon budget studies. Global climate models project widespread summer drying in midlatitude regions during the twenty-first century (Solomon et al. 2007). Such drying may have larger impacts on the terrestrial carbon dynamics in these regions. The positive effects of increasing temperature and atmospheric $\mathrm{CO}_{2}$ concentrations on ecosystem carbon sequestration (Norby et al. 2005) will likely be counteracted to some extent by severe extended droughts, leading to a reduced carbon sink or even a source during the drought periods. The effects of future droughts on terrestrial carbon dynamics in midlatitude regions thereby may constitute a positive feedback to the global climate system.

Acknowledgments. This research is partly supported by National Science Foundation (NSF-0554811). We obtained the CRU TS 2.1 data from Dr. David Viner; the DISCover data from USGS EROS Data Center; the PDSI algorithms from the University of Nebraska, Lincoln; the elevation and NDVI data from the Global Land Cover Facility; the crop yield data from the Chinese Ministry of Agriculture; and the water-holding capacity data from the Oak Ridge National Laboratory Distributed Active Archive Center (ORNL DAAC). We thank Dr. Tonglin Zhang and Dr. Aiguo Dai for helpful discussion, Jinyun Tang and Bill Whitson for help with supercomputing, and Rose Filley for editorial comments. We also thank Dr. Xiangming Xiao, Dr. Yude Pan, and two anonymous reviewers for their constructive comments on an earlier version of the manuscript. 
Earth Interactions - Volume 13 (2009) - Paper No. 10 • Page 27

\section{References}

Albani, M., D. Medvigy, G. C. Hurtt, and P. R. Moorcroft, 2006: The contributions of land-use change, $\mathrm{CO}_{2}$ fertilization, and climate variability to the Eastern US carbon sink. Global Change Biol., 12, 2370-2390.

Amthor, J. S., and Coauthors, 2001: Boreal forest $\mathrm{CO}_{2}$ exchange and evapotranspiration predicted by nine ecosystem process models: Intermodel comparison and relationships to field measurements. J. Geophys. Res., 106, 33 623-33 648.

Battaglia, M., M. L. Cherry, C. L. Deadle, P. J. Sands, and A. Hingston, 1998: Prediction of leaf area index in eucalypt plantations: Effect of water stress and temperature. Tree Physiol., 18, 521-528.

Belward, A. S., J. E. Estes, and K. D. Kline, 1999: The IGBP-DIS global 1-km land-cover data set DISCover: A project overview. Photogramm. Eng. Remote Sens., 65, 1013-1020.

Bonsal, B., and M. Regier, 2007: Historical comparison of the 2001/2002 drought in the Canadian prairies. Climate Res., 33, 229-242.

Bordi, I., K. Fraedrich, J.-M. Jiang, and A. Sutera, 2004: Spatio-temporal variability of dry and wet periods in eastern China. Theor. Appl. Climatol., 79, 81-91.

Bréda, N., R. Huc, A. Granier, and E. Dreyer, 2006: Temperate forest trees and stands under severe drought: Review of ecophysiological responses, adaptation processes and long-term consequences. Ann. For. Sci., 63, 625-644.

Cao, M. K., S. D. Prince, K. R. Li, B. Tao, J. Small, and X. M. Shao, 2003: Response of terrestrial carbon uptake to climate interannual variability in China. Global Change Biol., 9, 536546.

Churkina, G., and S. W. Running, 1998: Contrasting climatic controls on the estimated productivity of global terrestrial biomes. Ecosystems, 1, 206-215.

Ciais, P., and Coauthors, 2005: Europe-wide reduction in primary productivity caused by the heat and drought in 2003. Nature, 437, 529-533.

Clein, J. S., B. L. Kwiatkowski, A. D. McGuire, J. E. Hobbie, E. B. Rastetter, J. M. Melillo, and D. W. Kicklighter, 2000: Modeling carbon responses of tundra ecosystems to historical and projected climate: A comparison of a plot and global-scale ecosystem model to identify process-based uncertainties. Global Change Biol., 6, 127-140.

Cook, E. R., and L. Kairiukstis, 1990: Methods of Dendrochronology: Applications in the Environmental Sciences. Kluwer Academic, 408 pp.

—, D. M. Meko, D. W. Stahle, and M. K. Cleaveland, 1999: Drought reconstructions for the continental United States. J. Climate, 12, 1145-1162.

— C. A. Woodhouse, C. M. Eakin, D. M. Meko, and D. W. Stahle, 2004: Long-term aridity changes in the western United States. Science, 306, 1015-1018.

Dai, A., K. E. Trenberth, and T. R. Karl, 1998: Global variations in droughts and wet spells: 19001995. Geophys. Res. Lett., 25, 3367-3370.

,$- \ldots$, and T. Qian, 2004: A global dataset of Palmer drought severity index for 1870-2002: Relationship with soil moisture and effects of surface warming. J. Hydrometeor., 5, 11171130.

— T. R. Karl, B. Sun, and K. E. Trenberth, 2006: Recent trends in cloudiness over the United States. Bull. Amer. Meteor. Soc., 87, 597-606.

Dai, X. G., C. B. Fu, and P. Wang, 2005: Interdecadal change of atmospheric stationary waves and north China drought. Chin. Phys., 14, 850-858.

Deng, Y. T., 1937: History of Famine Relief in China (in Chinese). Commercial Press, 376 pp.

dos Santos, R. M. N., and A. R. Pereira, 1999: Palmer drought severity index for western Sao Paulo state, Brazil. Rev. Bras. Agrometeor., 7, 139-145.

Etheridge, D. M., L. P. Steele, R. L. Langenfelds, R. J. Francey, J. M. Barnola, and V. I. Morgan, 1996: Natural and anthropogenic changes in atmospheric $\mathrm{CO}_{2}$ over the last 1000 years from air in Antarctic ice and firn. J. Geophys. Res., 101, 4115-4128. 
Earth Interactions - Volume 13 (2009) - Paper No. 10 • Page 28

Food and Agriculture Organization-United Nations Educational, Scientific, and Cultural Organization (FAO-UNESCO), cited 1971: Soil map of the world, 1:5,000,000. [Available online at http://www.lib.berkeley.edu/EART/fao.html.]

Fu, C. B., and Z. M. Zeng, 2005: Correlations between North Atlantic Oscillation Index in winter and eastern China flood/drought index in summer in the last 530 years. Chin. Sci. Bull., 50, 2505-2516.

Gorissen, A., A. Tietema, N. N. Joosten, M. Estiarte, J. Peñuelas, A. Sowerby, B. A. Emmett, and B. Claus, 2004: Climate change affects carbon allocation to the soil in shrublands. Ecosystems, 7, 650-661.

Granier, A., N. Breda, P. Piron, and S. Vilette, 1999: A lumped water balance model to evaluate duration and intensity of drought constraints in forest stands. Ecol. Modell., 116, 269-283.

Graumlich, L. J., L. B. Brubaker, and C. C. Grier, 1989: Long-term trends in forest net primary productivity: Cascade Mountains, Washington. Ecology, 70, 405-410.

Hicke, J. A., and D. B. Lobell, 2004: Spatiotemporal patterns of cropland area and net primary production in the central United States estimated from USDA agricultural information. Geophys. Res. Lett., 31, L20502, doi:10.1029/2004GL020927.

Hogg, E. H., J. P. Brandt, and M. Michaellian, 2008: Impacts of a regional drought on the productivity, dieback, and biomass of western Canadian aspen forests. Can. J. For. Res., 38, 1373-1384.

Hurtt, G. C., S. W. Pacala, P. R. Moorcroft, J. Caspersen, E. Sheviakova, R. A. Houghton, and B. Moore III, 2002: Projecting the future of the U.S. carbon sink. Proc. Natl. Acad. Sci. USA, 99, 1389-1394.

Jacoby, G. C., and R. D. D'Arrigo, 1997: Tree rings, carbon dioxide, and climatic change. Proc. Natl. Acad. Sci. USA, 94, 8350-8353.

Karl, T. R., and P. M. Steurer, 1990: Increased cloudiness in the United States during the first half of the twentieth century: Fact or fiction? Geophys. Res. Lett., 17, 1925-1928.

Keeling, C. D., and T. P. Whorf, 2005: Atmospheric $\mathrm{CO}_{2}$ records from sites in the SIO air sampling network. Trends: A Compendium of Data on Global Change, Carbon Dioxide Information Analysis Center, Oak Ridge National Laboratory, U.S. Department of Energy.

Kirschbaum, M. U. F., 1995: The temperature dependence of soil organic matter decomposition, and the effect of global warming on soil organic C storage. Soil Biol. Biochem., 27, 753-760.

Krakauer, N. Y., and J. T. Randerson, 2003: Do volcanic eruptions enhance or diminish net primary production? Evidence from tree rings Global Biogeochem. Cycles, 17, 1118, doi:10.1029/ 2003 GB002076.

Krishnan, P., B. T. T. A. Black, N. J. Grant, A. G. Barr, E. H. Hogg, R. S. Jassal, and K. Morgenstern, 2006: Impact of changing soil moisture distribution on net ecosystem productivity of a boreal aspen forest during and following drought. Agric. For. Meteor, 139, 208-223.

Law, B. E., A. H. Goldstein, P. M. Anthoni, M. H. Unsworth, J. A. Panek, M. R. Bauer, J. M. Fracheboud, and N. Hultman, 2001: $\mathrm{CO}_{2}$ and water vapor exchange by young and old ponderosa pine ecosystems during a dry summer. Tree Physiol., 21, 299-308.

_ - and Coauthors, 2002: Environmental controls over carbon dioxide and water vapor exchange of terrestrial vegetation. Agric. For. Meteor., 113, 97-120.

Leal, S., T. M. Melvin, M. Grabner, R. Wimmer, and K. R. Briffa, 2007: Tree-ring growth variability in the Austrian Alps: The influence of site, altitude, tree species and climate. Boreas, 36, 426-440.

LeBlanc, D. C., 1996: Using tree rings to study forest decline: An epidemiological approach based on estimated annual wood volume increment. Proc. Int. Conf. Tree Rings, Environment and Humanity, J. S. Dean, D. M. Meko, and T. W. Swetnam, Eds., Radiocarbon, Department of Geoscience, University of Arizona, Tucson, AZ, 437-449.

Le Dantec, V., E. Dufréne, and B. Saugier, 2000: Interannual and spatial variation in maximum leaf area index of temperate deciduous stands. For. Ecol. Manage., 134, 71-81.

Li, J., 1989: Xinjiang Dendroclimatological and Dendrohydrological Studies (in Chinese with English abstract). China Meteorological Press, 268 pp. 
Earth Interactions - Volume 13 (2009) - Paper No. 10 • Page 29

— X. Xou, E. R. Cook, and F. Chen, 2006: Tree-ring based drought reconstruction for the central Tien Shan area in northwest China. Geophys. Res. Lett., 33, L07715, doi:10.1029/ 2006 GL025803.

Li, J. H., D. P. Johnson, P. Dukstra, B. A. Hungate, C. R. Hinkle, and B. G. Drake, 2007: Elevated $\mathrm{CO}_{2}$ mitigates the adverse effects of drought on daytime net ecosystem $\mathrm{CO}_{2}$ exchange and photosynthesis in a Florida scrub-oak ecosystem. Photosynthetica, 45, 51-58.

Li, M., Z. Li, D. Wang, X. Yang, X. Zhong, Z. Li, and Y. Li, 2005: Impacts of natural disasters on crop yields during the last fifty years (in Chinese). J. Nat. Disasters, 14, 55-60.

Li, X., X. Zhan, and X. Wu, 1992: Preliminary study on drought/wet variation over last 250 years in Baotou area using tree ring data (in Chinese with English abstract). Sci. Geogr. Sin., 12, $143-152$.

Liang, E., and Coauthors, 2006: The 1920s drought recorded by tree rings and historical documents in the semi-arid and arid areas of northern china. Climatic Change, 79, 403-432.

Lloyd-Hughes, B., and M. A. Saunders, 2002: A drought climatology for Europe. Int. J. Climatol., 22, 1571-1592.

Loveland, T. R., B. C. Reed, J. F. Brown, D. O. Ohlen, J. Zhu, L. Yang, and J. W. Merchant, 2000: Development of a global land cover characteristics database and IGBP DISCover from 1-km AVHRR data. Int. J. Remote Sens., 21, 1303-1330.

Luo, Y., S. Wan, D. Hui, and L. L. Wallace, 2001: Acclimation of soil respiration to warming in a tall grass prairie. Nature, 413, 622-625.

Ma, Z. G., and C. B. Fu, 2006: Some evidence of drying trend over northern China from 1951 to 2004. Chin. Sci. Bull., 51, 2913-2925.

Manderscheid, R., and H. J. Weigel, 2007: Drought stress effects on wheat are mitigated by atmospheric $\mathrm{CO}_{2}$ enrichment. Agron. Sustainable Dev., 27, 79-87.

McGuire, A. D., J. M. Melillo, L. A. Joyce, D. W. Kicklighter, A. L. Grace, B. Moore III, and C. J. Vorosmarty, 1992: Interactions between carbon and nitrogen dynamics in estimating net primary productivity for potential vegetation in North America. Global Biogeochem. Cycles, 6, 101-124.

- - and Coauthors, 2001: Carbon balance of the terrestrial biosphere in the twentieth century: Analyses of $\mathrm{CO}_{2}$, climate and land use effects with four process-based ecosystem models. Global Biogeochem. Cycles, 15, 183-206.

Melillo, J. M., A. D. McGuire, D. W. Kicklighter, B. Moore III, C. J. Vorosmarty, and A. L. Schloss, 1993: Global climate change and terrestrial net primary production. Nature, 363, 234-240.

Mika, J., S. Horvath, L. Makra, and Z. Dunkel, 2005: The Palmer Drought Severity Index (PDSI) as an indicator of soil moisture. Phys. Chem. Earth, 30, 223-230.

Mitchell, T. D., and P. D. Jones, 2005: An improved method of constructing a database of monthly climate observations and associated high-resolution grids. Int. J. Climatol., 25, 693-712.

Mu, Q., M. Zhao, S. W. Running, M. Liu, and H. Tian, 2008: Contribution of increasing CO and climate change to the carbon cycle in China's ecosystems. J. Geophys. Res., 113, G01018, doi:10.1029/2006JG000316.

Nemani, R. R., C. D. Keeling, H. Hashimoto, W. M. Jolly, S. C. Piper, C. J. Tucker, R. B. Tucker, and S. W. Running, 2003: Climate-driven increases in global terrestrial net primary production from 1982 to 1999. Science, 300, 1560-1563.

New, M., M. Hulme, and P. D. Jones, 2000: Representing twentieth century space-time climate variability. Part II: Development of 1901-96 monthly grids of terrestrial surface climate. J. Climate, 13, 2217-2238.

Norby, R. J., and Coauthors, 2005: Forest response to elevated $\mathrm{CO}_{2}$ is conserved across a broad range of productivity. Proc. Natl. Acad. Sci. USA, 102, 18 052-18 056.

Ntale, H. K., and T. Y. Gan, 2003: Drought indices and their application to East Africa. Int. J. Climatol., 23, 1335-1357.

Orwig, D. A., and M. D. Abrams, 1997: Variation in radial growth responses to drought among species, site, and canopy strata. Trees, 11, 474-484. 


\section{Earth Interactions - Volume 13 (2009) - Paper No. 10 • Page 30}

Pacala, S. W., and Coauthors, 2001: Consistent land- and atmosphere-based U.S. carbon sink estimates. Science, 292, 2316-2320.

Palmer, W. C., 1965: Meteorological drought. Research Paper 45, U.S. Dept. of Commerce, 58 pp.

Pedersen, L. B., and J. Bille-Hansen, 1999: A comparison of litterfall and element fluxes in even aged Norway spruce, sitka spruce and beech stands in Denmark. For. Ecol. Manage., 114, 55-70.

Qian, W., Q. Hu, Y. Zhu, and D. K. Lee, 2003: Centennial-scale dry-wet variations in East Asia. Climate Dyn., 21, 77-89.

Qian, Y., D. P. Kaiser, L. R. Leung, and M. Xu, 2006: More frequent cloud-free days and less surface solar radiation in China from 1955 to 2000. Geophys. Res. Lett., 33, L01812, doi:10.1029/2005GL024586.

Raich, J. W., and Coauthors, 1991: Potential net primary productivity in South America: Application of a global model. Ecol. Appl., 1, 399-429.

Rambal, S., J. M. Ourcival, R. Joffre, F. Mouillot, Y. Mouvellon, M. Reichstein, and A. Rocheteau, 2003: Drought controls over conductance and assimilation of a Mediterranean evergreen ecosystem: Scaling from leaf to canopy. Global Change Biol., 9, 1813-1824.

Rathgeber, C., A. Nicault, J. Guiot, T. Keller, and P. Roche, 2000: Simulated responses of Pinus halepensis forest productivity to climatic change and $\mathrm{CO}_{2}$ increase using a statistical model. Global Planet. Change, 26, 405-421.

Reichstein, M., and Coauthors, 2003: Inverse modeling of seasonal drought effects on canopy $\mathrm{CO}_{2} /$ $\mathrm{H}_{2} \mathrm{O}$ exchange in three Mediterranean ecosystems. J. Geophys. Res., 108, 4726, doi:10.1029/ 2003JD003430.

Ren, W., H. Tian, M. Liu, C. Zhang, G. Chen, S. Pan, B. Felzer, and X. Xu, 2007: Effects of tropospheric ozone pollution on net primary productivity and carbon storage in terrestrial ecosystems of China. J. Geophys. Res., 112, D22S09, doi:10.1029/2007JD008521.

Sadras, V. O., and S. P. Milroy, 1996: Soil-water thresholds for the response of leaf expansion and gas exchange: A review. Field Crops Res., 47, 253-266.

Schimel, J. P., J. M. Gulledge, J. S. Clein-Curley, J. E. Lindstrom, and J. F. Braddock, 1999: Moisture effects on microbial activity and community structure in decomposing birch litter in the Alaskan taiga. Soil Biol. Biochem., 31, 831-838.

Schubert, S. D., M. J. Suarez, P. J. Pegion, R. D. Koster, and J. T. Bacmeister, 2004: On the cause of the 1930s dust bowl. Science, 303, 1855-1859.

Shao, X., and X. Wu, 1994: Radial growth of Huashan pine and its response to climate. J. Chin. Geogr., 4, 88-102.

— - X. Fang, H. B. Liu, and L. Huang, 2003: Dating the 1000-year old qilian juniper along the eastern margin of the Qaidam basin. Acta Geogr. Sin., 58, 90-100.

— L L. Huang, H. Liu, E. Liang, and X. Fang, 2005: Reconstruction of precipitation variation from tree rings in recent 1000 years in Delingha, Qinghai. Sci. China, 48, 939-949.

Shi, P., J. Wang, Y. Xie, P. Wang, and W. Zhou, 1997: A preliminary study of the climatic change, natural disasters of agriculture and grain yield in China during the past 15 years. J. Nat. Disasters, 12, 197-203.

Solomon, S., D. Qin, M. Manning, M. Marquis, K. Averyt, M. M. B. Tignor, H. L. Miller Jr., and Z. Chen, 2007: Climate Change 2007: The Physical Science Basis. Cambridge University Press, 996 pp.

$\mathrm{Su}$, M., and H. Wang, 2007: Relationship and its instability of ENSO-Chinese variations in droughts and wet spells. Sci. China, 50, 145-152.

Sutton, M. A., D. Simpson, P. E. Levy, I. Rognvald, S. Reis, M. Van Oijen, and W. de Vries, 2008: Uncertainties in the relationship between atmospheric nitrogen deposition and forest carbon sequestration. Global Change Biol., 14, 2057-2063.

Szep, I. J., J. Mika, and Z. Dunkel, 2005: Palmer drought severity index as soil moisture indicator: Physical interpretation, statistical behavior and relation to global climate. Phys. Chem. Earth, 30, 231-243. 


\section{Earth Interactions - Volume 13 (2009) - Paper No. 10 • Page 31}

Tian, H., J. M. Melillo, D. W. Kicklighter, A. D. McGuire, and J. Helfrich, 1999: The sensitivity of terrestrial carbon storage to historical climate variability and atmospheric $\mathrm{CO}_{2}$ in the Untied States. Tellus, 51B, 414-452.

Trusilova, K., and G. Churkina, 2008: The response of the terrestrial biosphere to urbanization: Land cover conversion, climate, and urban pollution. Biogeosciences, 5, 1505-1515.

van der Schrier, G., K. R. Briffa, T. J. Osborn, and E. R. Cook, 2006: Summer moisture available across North America. J. Geophys. Res., 111, D11102, doi:10.1029/2005JD006745.

Vasconcelos, S. S., D. J. Zarin, M. M. Araujo, L. G. Turbay, R.-V. Vasconcelos, C. J. R. de Carvalho, C. L. Staudhammer, and F. de Assis Oliveira, 2008: Effects of seasonality, litter removal and dry-season irrigation on litterfall quantity and quality in eastern Amazonian forest regrowth, Brazil. J. Trop. Ecol., 24, 27-38.

Vörösmarty, C. J., B. Moore III, A. L. Grace, M. P. Gildea, J. M. Melillo, B. J. Peterson, E. B. Rastetter, and P. A. Steudler, 1989: Continental scale models of water balance and fluvial transport: An application to South America. Global Biogeochem. Cycles, 3, 241-265.

Webb, R. W., C. E. Rosenzweig, and E. R. Levine, cited 2000: Global soil texture and derived waterholding capacities. [Available online at http://daac.ornl.gov/SOILS/guides/Webb.html.]

Xiao, J., and A. Moody, 2004: Trends in vegetation activity and their climatic correlates: China 1982 to 1998. Int. J. Remote Sens., 25, 5669-5689.

_ and Q. Zhuang, 2007: Drought effects on large fire activity in Canadian and Alaskan forests. Environ. Res. Lett., 2, 044003, doi:10.1088/1748-9326/2/4/044003.

Xin, X. G., R. C. Yu, T. J. Zhou, and B. Wang, 2006: Drought in late spring of South China in recent decades. J. Climate, 19, 3197-3206.

Yu, Q., 2003: Study of drought and drought disaster problems in China (in Chinese). China Water Resour., 7, 68-69.

Yuan, Y. J., J. F. Li, and J. B. Zhang, 2001: 348-year precipitation reconstruction from tree rings for the north slope of the middle Tianshan Mountains. Acta Meteor. Sin., 15, 95-104.

Zeng, N., H. Qian, C. Roedenbeck, and M. Heimann, 2005: Impact of 1998-2002 midlatitude drought and warming on terrestrial ecosystem and the global carbon cycle. Geophys. Res. Lett., 32, L22709, doi:10.1029/2005GL024607.

Zhang, J., 1994: The dendroclimate's reconstruction and dendroclimate's regional differentiation research in eastern and western agriculture-animal husbandry zone in Inner Mongolia (in Chinese with English abstract). M.S. thesis, Department of Geography, Beijing Normal University, Beijing, China, 36 pp.

_ Z Z. Wu, and J. Li, 1996: Utilizing tree ring chronologies to reconstruct 300-year drought days in eastern Tianshan Mountains. Quart. J. Appl. Meteor., 7, 53-60.

Zhuang, Q., A. D. McGuire, K. P. O'Neill, J. W. Harden, V. E. Romanovsky, and J. Yarie, 2002: Modeling soil thermal and carbon dynamics of a fire chronosequence in interior Alaska. J. Geophys. Res., 107, 8147, doi:10.1029/2001JD001244.

_ - and Coauthors, 2003: Carbon cycling in extratropical terrestrial ecosystems of the Northern Hemisphere during the 20th century: A modeling analysis of the influences of soil thermal dynamics. Tellus, 55B, 751-776.

Zou, X., P. Zhai, and Q. Zhang, 2005: Variations in droughts over China: 1951-2003. Geophys. Res. Lett., 32, L04707, doi:10.1029/2004GL021853.

Earth Interactions is published jointly by the American Meteorological Society, the American Geophysical Union, and the Association of American Geographers. Permission to use figures, tables, and brief excerpts from this journal in scientific and educational works is hereby granted provided that the source is acknowledged. Any use of material in this journal that is determined to be "fair use" under Section 107 or that satisfies the conditions specified in Section 108 of the U.S. Copyright Law (17 USC, as revised by P.IL. 94553) does not require the publishers' permission. For permission for any other from of copying, contact one of the copublishing societies. 